
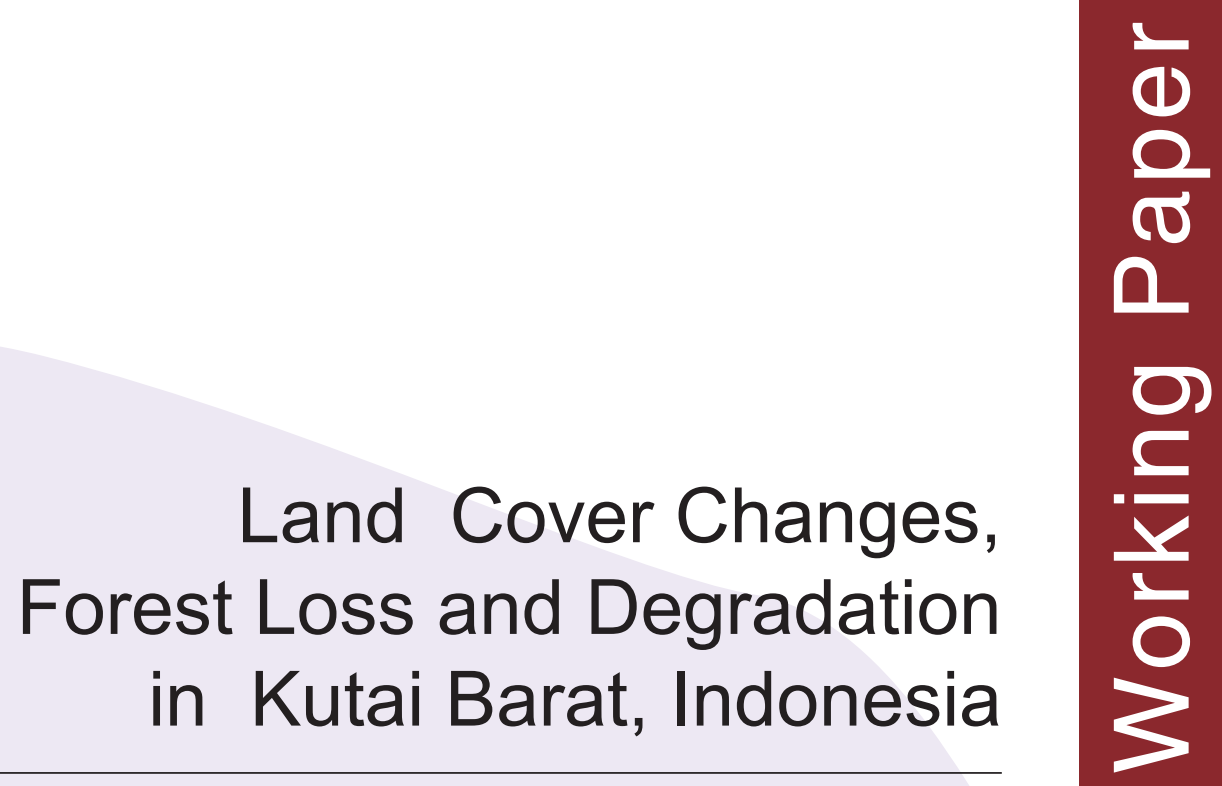

Mukhammad Thoha Zulkarnain, Chandra Irawadi Wijaya and Atiek Widayati 



\section{Land Cover Changes, Forest Loss and Degradation in Kutai Barat, Indonesia}

Mukhammad Thoha Zulkarnain, Chandra Irawadi Wijaya and Atiek Widayati

Working Paper No. 188 


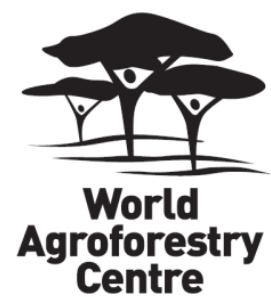

\section{Correct citation:}

Zulkarnain MT, Wijaya CI, and Widayati A. 2014. Land Cover Changes, Forest Loss and Degradation in Kutai Barat, Indonesia. Working Paper No. 188. Bogor, Indonesia. World Agroforestry Centre (ICRAF), Southeast Asia Regional Program. 34p. DOI: 10.5716/WP14145.PDF.

Titles in the Working Paper Series aim to disseminate interim results on agroforestry research and practices and stimulate feedback from the scientific community. Other publication series from the World Agroforestry Centre include: Agroforestry Perspectives, Technical Manuals and Occasional Papers.

Published by the World Agroforestry Centre (ICRAF)

Southeast Asia Regional Program

PO Box 161, Bogor 16001

Indonesia

Tel: +62 2518625415

Fax: +62 2518625416

Email: icraf-indonesia@cgiar.org

http://worldagroforestrycentre.org/regions/southeast_asia

(C) World Agroforestry Centre 2014

Working Paper No. 188

\section{Photos:}

The views expressed in this publication are those of the author(s) and not necessarily those of the World Agroforestry Centre.

Articles appearing in this publication may be quoted or reproduced without charge, provided the source is acknowledged.

All images remain the sole property of their source and may not be used for any purpose without written permission of the source. 


\section{About the authors}

\section{Mukhammad Thoha Zulkarnain}

Mukhammad Thoha Zulkarnain is a Remote Sensing Associate on World Agroforestry Centre.

Thoha's area of expertise on Remote sensing data processing, land use/ cover change, driver on land use change, emission estimation on landscape scale, natural resource management, spatial planning and mostly work on multidisciplinary research. The background of Thoha's education is soil science from Brawijaya University for his bachelor degree and currently, he is also as a student on Information Technology for Natural Resource Management on Bogor Agriculture University SEAMO BIOTROP for his master degree. He works effectively in trans-discipline research while also working with farmer and community group, local and national government agencies, NGO's and other research institute in some task such as: focus group discussion and Trainings. He also has extensive experience in providing technical assistance to local and national government to do research related to spatial planning for low emission development strategies.

Contact: m.zulkarnain@cgiar.org

\section{Chandra Irawadi Wijaya}

Chandra Irawadi Wijaya is a Geographic Information System (GIS) Specialist on World Agroforestry Centre. Chandra works on multidisciplinary research with area of interest on forestry, forest resources conservation, natural resources management, land use/cover changes modeling, drivers of land use/cover changes, land use planning, payment/rewards for environmental services, hydrological modeling, and spatial data infrastructure. He took his master degree on Information Technology for Natural Resource Management at Bogor Agriculture University, and on Forest Resources Conservation for his bachelor degree at the same university. He has extensive experience in providing capacity building to local and national government on GIS and spatial data infrastructure as well as technical assistance to develop land use planning for low emission development strategies.

Contact: c.wijaya@cgiar.org 


\section{Atiek Widayati}

Atiek Widayati, $\mathrm{PhD}$, is a senior landscape-geospatial analyst with an extensive experience in the areas of climate change mitigation, low emission development, vulnerability assessments and livelihood and conservation approaches. She has been with ICRAF for around eight years and currently leads the Spatial Analyses Unit of ICRAF Indonesia. Within the context of mitigating climate change, her experience includes topics on land use and land cover changes and the consequences on aboveground emission and opportunity costs, drivers of land use changes, landscape dynamics and biomass/carbon stock assessments in forest-agroforest-agriculture environments and community-based forest management. Her expertise also includes developing livelihoodconservation strategies in the context of maintenance of ecosystem services and adaptation to environmental changes through agroforest landscape and participatory and multistakeholder-based livelihood-conservation strategy development.

Contact: a.widayati@cgiar.org 


\section{Abstract}

As part of efforts on Reducing Emissions from Deforestation and Degradation (REDD+) and low $\mathrm{CO}_{2}$ emission development planning for Kutai Barat district, East Kalimantan, Indonesia, it is important to obtain estimates of the land cover changes and the change trajectories. The information is useful for further assessments on $\mathrm{CO}_{2}$ emissions, trade-off as well as for inputs in land use planning. The objectives of the study are to produce four time series of land cover data, to analyze land cover changes and trajectories in the district, and to analyze forest deforestation and degradation in Kutai Barat District. Four time series Landsat Imageries (1990, 2000, 2005 and 2010) were utilised, and herarchichal object-based classification method was employed for the map production. The result demonstrates that most of forest loss in Kutai Barat during 1990 - 2010 was caused by changes from degraded forest (especially open and closed Tree.Evergreen-broadleaved) to rubber agroforests, rubber plantations and shrub land; this latter change implying forest degradation due to timber extraction. Most forest loss and forest degradation occur in Production Forest zones (Hutan Produksi) where tree cutting is legal. However, there is as well degradation taking place in Protection Forest zone (Hutan Lindung) which implies illegal activities. For a district where natural resources still play a major role in the development and economic growth, locally appropriate strategies on land-use planning and its implementation should be comprehensively designed in order to maintain good environmental practices.

\section{Keywords}

Land cover changes, forest degradation, deforestation, trajectories, hierarchical object-based classification 


\section{Acknowledgements}

This working paper is a deliverable of I-REDD project, funded by The European Union and implemented collaboratively by the World Agroforestry Centre (ICRAF) Southeast Asia and the World Wide Fund for Nature (WWF) Indonesia for Kutai Barat site. Contributions, comments and review for this working paper by Arif Budiman and Dirk Pflugmacher are highly appreciated. 


\section{Contents}

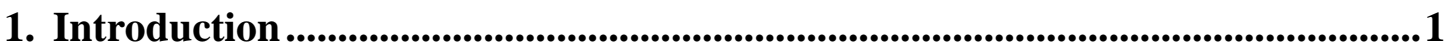

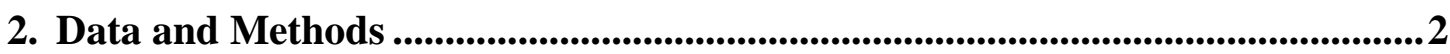

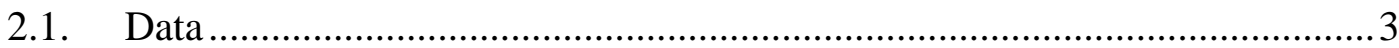

2.1.1. Satellite Imageries .................................................................... 3

2.1.2. Ground Truth Data ................................................................... 3

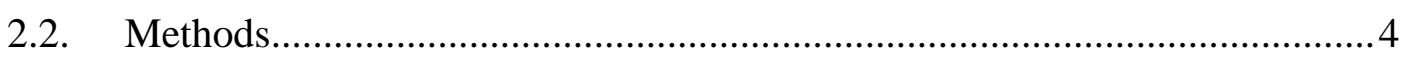

2.2.1. Image pre-processing ......................................................... 4

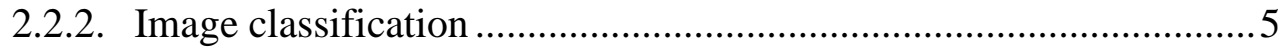

2.2.3. Post interpretation analysis ...................................................... 7

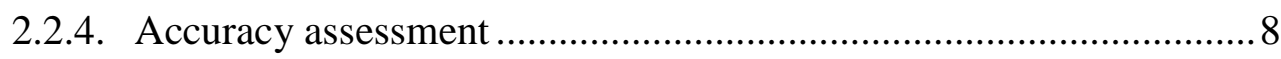

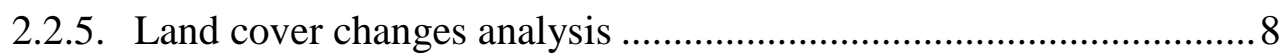

2.2.6. Rate of deforestation and forest degradation ............................... 8

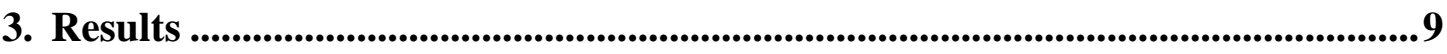

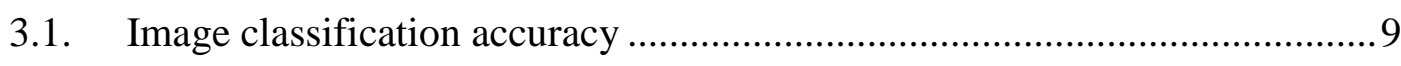

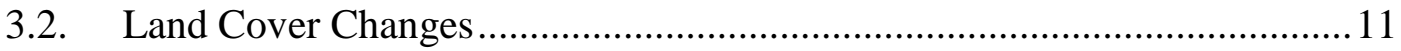

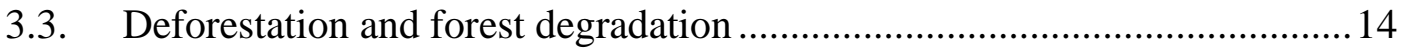

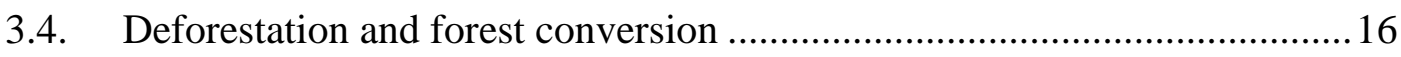

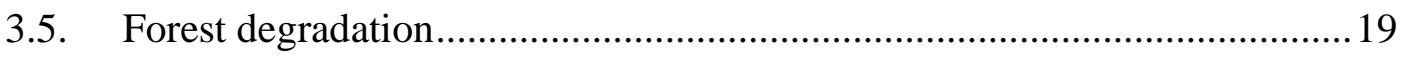

4. Discussions .........................................................................................................................19

5. Conclusion/recommendations ............................................................................................21

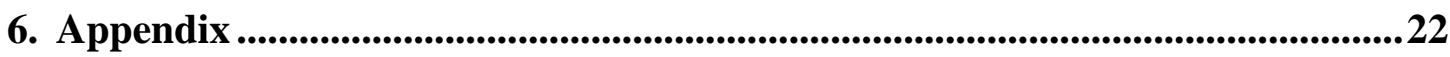

6.1. Appendix 1. Description of land cover classes .........................................22

6.2. Appendix 2. Error matrix of land cover map 2010 .................................24

6.3. Appendix 3. Accuracy of each land cover category in land

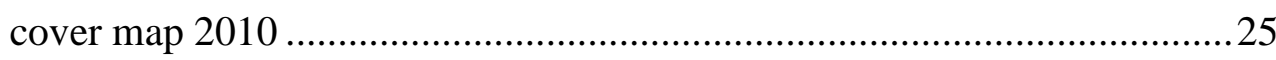

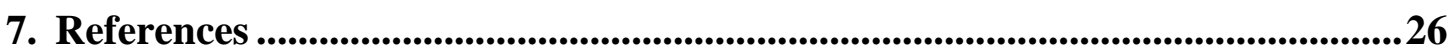





\section{Introduction}

Kutai Barat District is located at $113^{\circ} 45^{\prime} 05^{\prime \prime}-116^{\circ} 31^{\prime} 19^{\prime \prime}$ East and between $1^{\circ} 31^{\prime} 35^{\prime \prime}$ North and $1^{\circ} 10^{\prime} 16^{\prime}$ 'South (Figure 1). The total area of Kutai Barat District is $31629 \mathrm{~km}^{2}$, with altitudes ranging 0-1500 $\mathrm{m}$ asl. The topography of Kutai Barat is dominated by sloping lands with more than $50 \%$ of it mountainous, mostly in the Northwestern part of the District. The mountainous parts of Kutai Barat are located upstream of Mahakam River, especially in the Long Bagun district, Long Pahangai district and Long Apari district.

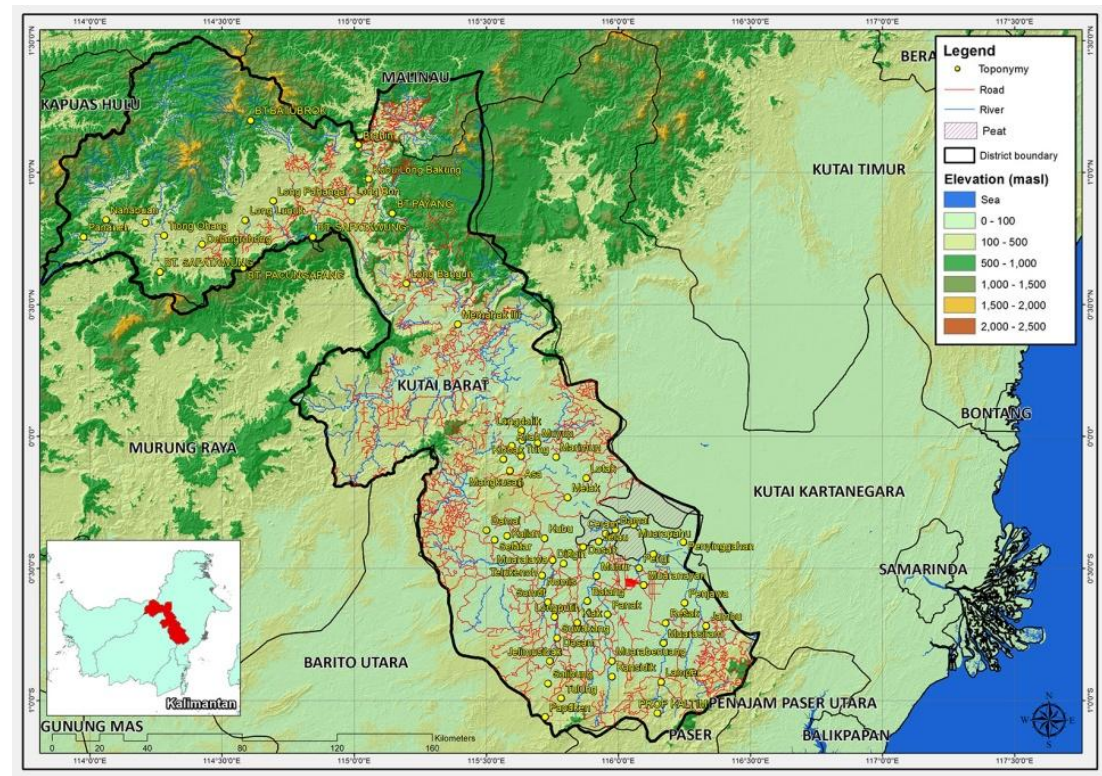

Figure 1. Location of Kutai Barat Regency in East Kalimantan, Indonesia

As part of the various ongoing work in Kutai Barat related to Reducing Emissions from Deforestation and Degradation plus conservation (REDD+) and Land Use Planning for Low Emission Development Strategies (LUWES) (Dewi et al, 2013), it is important to obtain estimates of the Land-Cover changes and the change trajectories, especially for tropical forest deforestation and forest degradation domains. Tropical deforestation accounted for approximately $12 \%$ of global anthropogenic $\mathrm{CO}_{2}$ emissions in 2008 (Van der Werf et al, 2009). Forest degradation from fire, logging and fuel wood collection represents an additional source of carbon emissions from Land-Use activities in tropical forest regions (Morton DC et al, 2011). According to Ekadinata et al, 2011, forest cover in Indonesia decreased from 128.72 million hectares in 1990 to 99.6 million hectares in 2005. The 2005 Land-Cover maps shows that $40 \%$ (38.5 million hectares) of forest cover is logged-over forest, demonstrating the decrease of forest cover caused by logging and other timber extraction activities.

Remote Sensing and Geographic Information Systems are the most efficient and effective tools to map and monitor Land-Cover changes and trajectories. Medium-resolution Landsat Imageries, which 
are publicly available, serve as cost-effective data to generate Land-Cover data at the district level and thus, is used as the main data source. However, common with optical remote sensors, loss of information due to cloud cover has become a major problem, especially when affecting large areas and/or it affects the precisely specific areas of interest. Active remote sensors such as the Synthetic Aperture Radar (SAR) has became one of the best solutions due to its ability to penetrate cloud cover. The capability to penetrate clouds is a major advantage of radar systems, with respect to optical systems. Furthermore, radar sensor provides information that is complementary to that of visible infrared imagery (Riedel et al, 2008). Zulkarnain et al, 2013, added that Land-Cover generated from fusion of Landsat and Alos Palsar image has a higher accuracy of about 3\% compared to Landsat imaging only.

The objectives of the study in this report are: (1) to produce four time series of Land-Cover data (1990, 2000, 2005 and 2010) of the Kutai Barat District, (2) to analyze Land-Cover changes and trajectories in the district, and (3) to analyze forest deforestation and degradation in the study site.

\section{Data and Methods}

This study made use of four time series (1990, 2000, 2005 and 2010) of Land-Cover data derived from satellite imageries to identify Land-Cover changes and forest cover changes (forest deforestation and degradation) in Kutai Barat. The general framework used to identify Land-Cover changes and forest cover changes is Analysis of Land-Use/cover Changes and Trajectories (ALUCT) (Dewi, 2010), which consists of three major stages: 1) image pre-processing, 2) image classification, 3) postclassification (Figure 2).

Before implementing this method, it is required to conduct inventories and to define classes of LandUse/cover in the study area. The classes are designed in such a way so that they are recognizable from the satellite imageries and cover all the dominant land-use/cover types that exist in the study area. A list of relevant land-use classes was developed based on the Land-Cover Classification System (LCCS) (Di Gregorio, 2005) with the exception of a few cases that were not possible to match with the LCCS classification scheme. The datasets intend to include, at least, the level of detail in the legend hierarchies (1) Land-Cover and (2) Land-Use (3) Hydrology (4) Disturbance history and 5) Additional Land-Cover characteristics and through field work in the study area. 


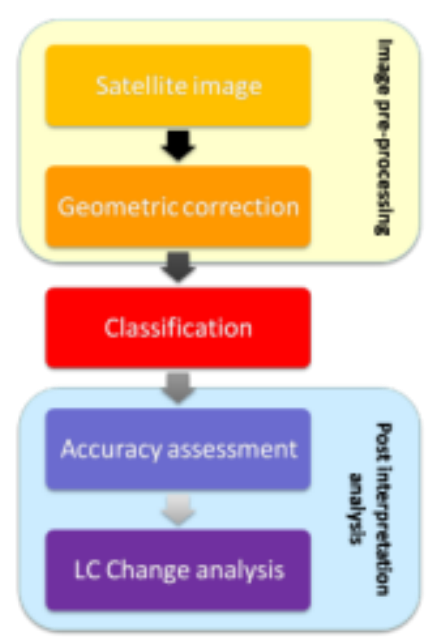

Figure 2. Overall flow of ALUCT framework

\subsection{Data}

\subsubsection{Satellite Imageries}

This study made use Landsat imageries that cover Kutai Barat with a spatial resolution of 30 meters. In addition, ALOS Palsar imageries with spatial resolution of 50 meters were also used as auxiliary imageries to produce land cover data of 2010. List of satellite imageries used for land cover mapping is shown in Table 1.

\subsubsection{Ground Truth Data}

Ground truth data is required to assist classification of satellite imagery as well as a reference to assess the accuracy of land cover 2010 produced in image classification. The ground truth data were taken from field survey that was conducted in 2012. The plan of field survey was designed by generating random point data which then was visualized in the form of maps together with spatial data of Kutai Barat in particular maps, such as Landsat imageries, road networks, river networks, and point locations. In the implementation stage, 358 ground were successfully obtained with GPS during the field survey, with 314 of these ground truth points qualified to be used as reference for accuracy assessment. Most ground truth points taken from field surveys may represent land cover classes that were derived from satellite imageries.

In addition, secondary data was also used to support the classification of satellite imagery. The data was obtained from various sources such as forest maps, road maps, river maps, administrative maps, and SRTM DEM. 
Table 1. List of satellite imageries

\begin{tabular}{|c|c|c|c|c|c|}
\hline Satellite imagery & $\begin{array}{l}\text { Time } \\
\text { series }\end{array}$ & $\begin{array}{l}\text { Path/ } \\
\text { Row }\end{array}$ & Acquisition date & $\begin{array}{l}\text { Spatial } \\
\text { resolution }\end{array}$ & Source \\
\hline \multirow[t]{5}{*}{ Landsat 5 TM } & \multirow[t]{5}{*}{1990} & $117 / 60$ & August 28, 1992 & \multirow[t]{5}{*}{$30 \mathrm{~m}$} & \multirow[t]{5}{*}{ USGS - NASA } \\
\hline & & $117 / 61$ & August 28, 1992 & & \\
\hline & & $118 / 59$ & December 28, 1990 & & \\
\hline & & $118 / 60$ & Jube 30, 1991 & & \\
\hline & & $119 / 59$ & July 25, 1992 & & \\
\hline \multirow[t]{5}{*}{ Landsat 7 ETM+ } & \multirow[t]{5}{*}{2000} & $117 / 60$ & August 26, 2000 & \multirow[t]{5}{*}{$30 \mathrm{~m}$} & \multirow[t]{5}{*}{ USGS - NASA } \\
\hline & & $117 / 61$ & August 26, 2000 & & \\
\hline & & $118 / 59$ & September 02, 2000 & & \\
\hline & & $118 / 60$ & September 02, 2000 & & \\
\hline & & $119 / 59$ & July 10, 2001 & & \\
\hline \multirow[t]{5}{*}{ Landsat 7 ETM+ } & \multirow[t]{5}{*}{2005} & $117 / 60$ & August 21, 2004 & \multirow[t]{5}{*}{$30 \mathrm{~m}$} & \multirow[t]{5}{*}{ USGS - NASA } \\
\hline & & $117 / 61$ & June 05, 2005 & & \\
\hline & & $118 / 59$ & April 09, 2005 & & \\
\hline & & $118 / 60$ & April 09, 2005 & & \\
\hline & & $119 / 59$ & August 19, 2004 & & \\
\hline \multirow[t]{5}{*}{ Landsat 7 ETM+ } & \multirow[t]{5}{*}{2010} & $117 / 60$ & December 12, 2010 & \multirow[t]{5}{*}{$30 \mathrm{~m}$} & \multirow[t]{5}{*}{ USGS - NASA } \\
\hline & & $117 / 61$ & August 03, 2009 & & \\
\hline & & $118 / 59$ & April 26, 2011 & & \\
\hline & & $118 / 60$ & March 25, 2011 & & \\
\hline & & $119 / 59$ & January 27, 2011 & & \\
\hline \multirow[t]{2}{*}{$\begin{array}{c}\text { ALOS Palsar } \\
\text { Mosaic }\end{array}$} & \multirow[t]{2}{*}{2010} & $\mathrm{~A} 03$ & $\begin{array}{c}\text { June } 12-\text { August } 19 \\
2009\end{array}$ & \multirow[t]{2}{*}{$50 \mathrm{~m}$} & \multirow[t]{2}{*}{ EORC, JAXA } \\
\hline & & A04 & $\begin{array}{c}\text { June } 12 \text { - August } 19, \\
2009\end{array}$ & & \\
\hline
\end{tabular}

\subsection{Methods}

\subsubsection{Image pre-processing}

Image pre-processing was needed in order to correct errors caused by interference from the atmosphere at the time of image recording, which consist of two activities: radiometric and geometric corrections. We used the ATCOR method for radiometric correction. The Atmospheric and 
Topographic Correction for Satellite Imagery (ATCOR) is a method used to reduce atmospheric and illumination effects on remotely sensed data to retrieve physical parameters of the earth's surface such as atmospheric conditions (emissivity, temperature), thermal and atmospheric radiance and transmittance functions in order to simulate the simplified properties of a 3D atmosphere (http://www.satimagingcorp.com/svc/atcor.html). Geometric correction aims to correct errors or geometric positions during the recording of satellite imagery, we also used 20 ground control points (GCPs) collected from reference datasets, in this case, Orthorectified Landsat 2000 image form the United States Geological Survey (USGS). We imposed geometric precision of 0.5 pixels $(15 \mathrm{~m})$ for each image.

\subsubsection{Image classification}

Image classification is the core processing method containing interpretations of spectral information in satellite images into land-use classes. The Hierarchical object-based classification (HOBC) approach (Blumberg and Zhu, 2007) is applied in producing the time series Land-Cover maps. In the $\mathrm{HOBC}$ approach, the procedure begins with an image segmentation process, which aims to produce image objects. An object is defined as a group of pixels with a similar level of homogeneity for their spectral and spatial characteristics (Figure 3). The determination for an image object has to meet the need to represent the actual earth landscape features on the satellite images. For this study, the smallest object size was determined to be 1 ha. Several phases of segmentation were conducted in order to obtain the required quality of detail at the different levels. The outputs of these phases are called multi-resolution image segments, which serve as a basis for the hierarchical classification system. 


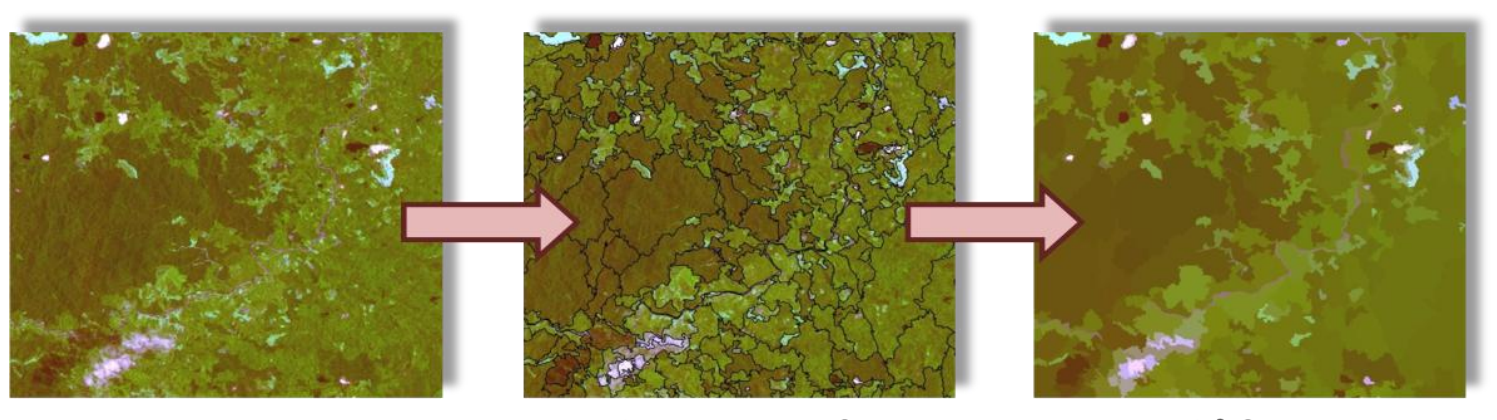

Image

Segmentation

Object

Figure 3. Segmentation process

Image classification was conducted using the hierarchical structure, shown in Figure 4. The hierarchy is divided into four levels, and in each level, land cover types are interpreted using spectral and spatial rules. A Land cover class scheme is developed as a combination of categories based on the criteria of: land cover type, forest classification, soil type, hydrology, crop system type and disturbance history. Details and complexity of land cover types increase in each level, therefore, each of them has different sets of rules applied.

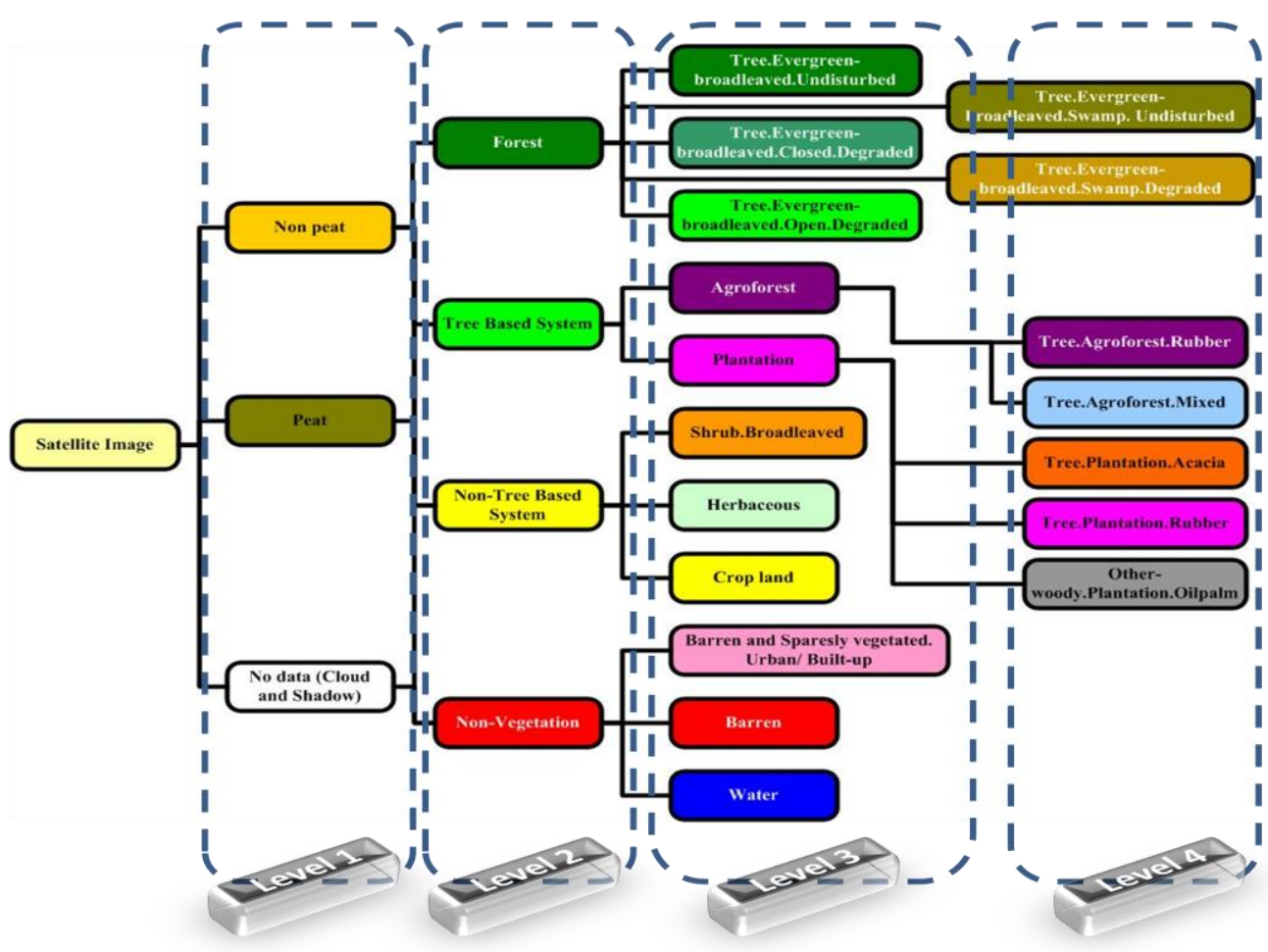

Figure 4. Hierarchical classification scheme

- Level 1 consists of general classes such as: Peat, Non peat and No Data (Cloud and Shadow).

These classes can be easily distinguished using visual inspections, simple spectral landsat bands and peat map. The result of Level 1 is further classified in Level 2. 
- Level 2 consists of general classes such as: Forest, Tree-based system, Non tree based system and Non vegetation. These classes can be easily distinguished using visual inspections and a simple vegetation index. The Vegetation index is a ratio of spectral value between a vegetation-sensitive channel (near infra red spectrum) and a non vegetation-sensitive channel (visible spectrum) in the satellite image. The result of Level 2 is further classified in Level 3.

- In Level 3, spectral value is not the only parameter using spatial characteristics such as oil palm maps, field references and Nearest Neighborhood algorithm is also used as a rule in classification. Nearest Neighborhood algorithm in object-based hierarchical classification is conducted in two steps: (1) Feature space optimization and (2) Classification (Definiens, 2007). The first step is conducted to calculate the combination of object features that produces the largest average minimum distance between the samples of the different classes. The combination of object features is used in the second steps to classify all objects into Land-Cover classes in level 3. Level 3 consists of 15 Land-Cover types such as ${ }^{1}$ : Tree.Evergreen-broadleaved.Unditurbed, Tree.Evergreen-broadleaved.Closed.Degraded, Tree.Evergreen-broadleaved.Open.Degraded, Tree.Evergreen-broadleaved.Swamp.Unditurbed, Tree.Evergreen-broadleaved.Swamp.Degraded, Tree.Evergreen-broadleaved.Peat swamp.Unditurbed, Tree.Evergreen-broadleaved.Peat swamp.Degraded, agroforest, monoculture plantation, Shrub.Broadleaved, Crop land, Herbaceous, Barren, Urban/Built-up and Water. Typically, for agroforest and monoculture plantation classes in Level 3, they are classified in more details in Level 4.

- In Level 4, similar parameters were applied to the smaller-size objects. Level 4 consists of 5 LandCover types such as: Tree.Agroforest.Rubber, Tree.Agroforest.Mixed, Tree.Plantation.Rubber, Other-woody.Plantation.Oilpalm and Tree.Plantation.Acacia. No data class (cloud and shadow) in the upper level are classified in level 4. In this level, backscatter value, field reference and nearest neighborhood algorithm was used as a rule in classification. ALOS Palsar image sampling is based on the appearance of a cloud-free Landsat imagery, or based on field references, while using with the value of backscatter from ALOS Palsar imagery as the parameter.

\subsubsection{Post interpretation analysis}

Post interpretation analysis consists of two stages: accuracy assessment and land cover change analysis. The accuracy assessment is to test the quality of the information derived from the image classification process by comparing field reference data with the most recent land-cover map. Furthermore, the land cover change analysis aims to get an overview of land cover changes and trajectories which may be analyzed further to derive the rate of deforestation and forest degradation in Kutai Barat.

\footnotetext{
${ }^{1}$ Following classification system defined under I-REDD project
} 


\subsubsection{Accuracy assessment}

Accuracy assessment was conducted by cross-tabulating the GPS points as reference data to the corresponding pixels in the output land cover map in a matrix, with the resulting percentage of correctly classified pixels were then used as the value for accuracy. To observe the consistency of the accuracy value, accuracy assessment was conducted by incorporating an increased number of sample points: $50 \%, 60 \%, 70 \%, 80 \%$ and $100 \%$ of the total number of collected 314 GPS points. The increasing sample points also considered a larger number of samples for each class, although spatial dependence across sample points was not considered.

\subsubsection{Land cover changes analysis}

Land cover changes analysis was done by overlaying four time series of land cover data to produce land covers changes and trajectory data during three periods (i.e. 1990-2000, 2000-2005, and 20052010) in Kutai Barat. Furthermore, the land cover changes data produced in three periods were overlaid with logging concession boundaries and state forest land designation maps from the Ministry of Forestry to capture the changes that occur at each zone. There are five designation zones in the state forest land in Kutai Barat: Production Forest (Hutan Produksi - HP), Limited Production Forest (Hutan Produksi Terbatas - HPT), Protection Forest (Hutan Lindung - HL), Natural Reserve (Cagar Alam) and Non-Forest Land (Area Penggunaan Lain-APL).

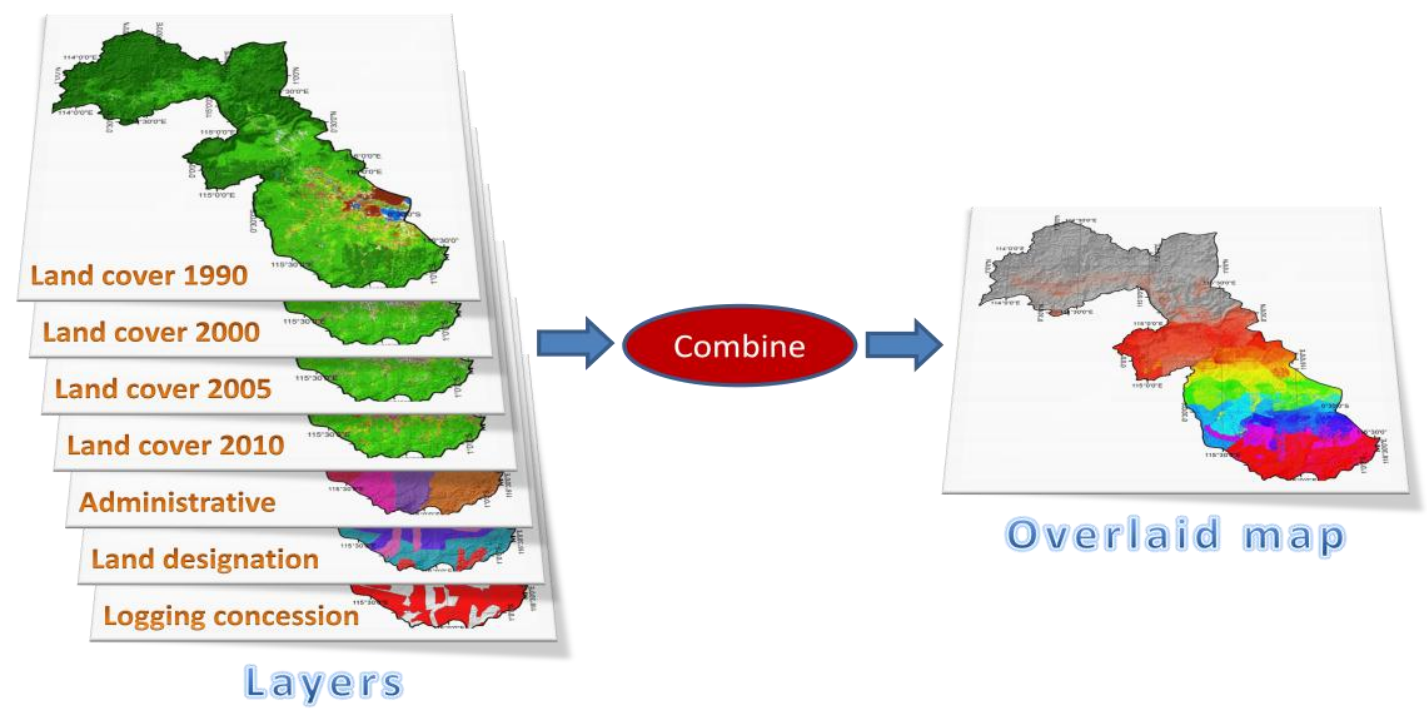

Figure 5. Illustration of overlay process

\subsubsection{Rate of deforestation and forest degradation}

Deforestation is defined as the conversion of forest to other Land-Uses or a long-term reduction of tree canopy cover below $10 \%$, whereas forest degradation is the reduction of the capacity or quality of forest to provide goods and services (FAO, 2010). To estimate forest deforestation and degradation from the detailed Land-Cover time series, we first grouped the Land-Cover types into three main classes: undisturbed forest, degraded forest, and non-forest. 
In practice, we distinguished between three natural forest types: evergreen-broadleaved forest on 1) mineral soil, 2) peat soil, and 3) swamps, with each of these forest types were then further classified as either undisturbed or degraded. Degraded forests on mineral soils were further separated into open canopy and closed canopy forests. Finally, we mapped a total of three undisturbed forest classes and four degraded forest classes, plus non-forest classes (see Table 2 and Table 3 in Chapter 3).

Based on the definitions from the FAO (2010) above, deforestation was estimated from the loss of undisturbed and degraded forest area, i.e. area of undisturbed forest changed to non-forest, plus the area of degraded forest that changed to non-forest. For forest degradation, the evaluation was based upon the changes from undisturbed forest to degraded forest. The annual rate of deforestation was estimated by applying Compound Interest Law (CIL) formula below (FAO, 1995):

$$
q=\left(A_{2} / A_{1}\right)^{1 /(t 2-t l)}-1
$$

where, $A_{1}$ and $A_{2}$ are the forest area at time $t_{1}$ and $t_{2}$.

CIL was also applied to estimate the annual rate of forest degradation by taking into account the residual undisturbed forest from the changes into degraded/disturbed forest. Forest degradation rate $(r)$ is calculated based on deforestation formulation which was modified by considering only forest classes.

$$
r=\left(\left(A_{i 1}-A_{j 2}\right) / A_{i 1}\right)^{1 /(t 2-t 1)}-1
$$

Where, $A_{i 1}$ is the undisturbed forest at time $1\left(t_{1}\right)$ and $A_{j 2}$ is the degraded forest during time $1\left(t_{1}\right)$ to time $2\left(t_{2}\right)$.

\section{Results}

\subsection{Image classification accuracy}

We collected a total of 358 ground truth points representing the various Land-Cover types in Kutai Barat (Figure 6) using GPS, of which as many as 314 ground truth points were used as reference for accuracy assessment. 


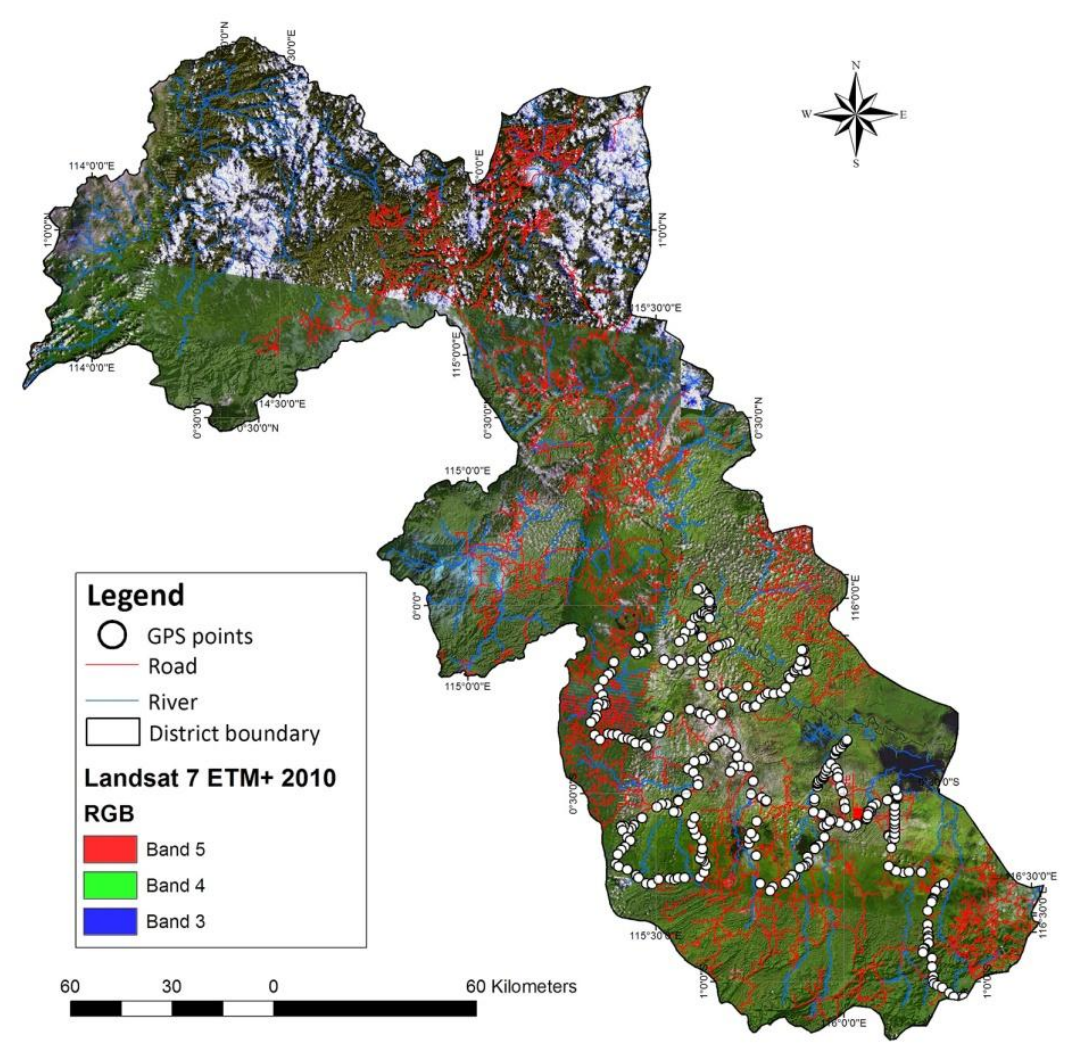

Figure 6. Distribution of ground truth points collected in 2012 in Kutai Barat

The accuracy assessment results demonstrate that overall accuracy of 2010 Land-Cover map is $76.11 \%$. The lowest accuracy $(73 \%)$ occurred when $50 \%$ of sample points were tested, and the highest (79\%) was when $60 \%$ of sample points were tested. These values indicate that the range of accuracy values is $73 \%-79 \%$, with an average of $76 \%$ (Figure 7).

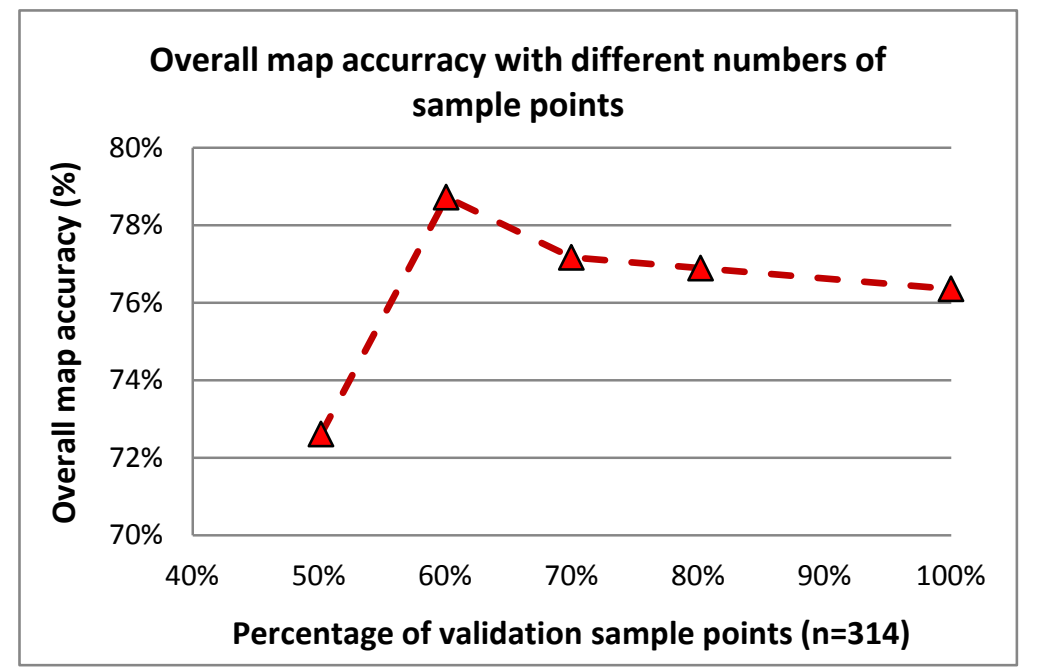

Figure 7. Variation of accuracy values for 2010 Kutai Barat Land Cover Map 
Misclassification occurs in rubber agroforests and rubber monocultures mostly due to the similar response shown by these two Land-Cover types in the satellite imagery. In the field, some vegetation cover in rubber agroforests is dominated by rubber plants and understory shrub, while the canopy cover was captured similarly as that of a monoculture system, although this only appears in small areas. Misclassification occurs also for logged-over forest and shrubs. This misclassification occurs as an impact of the vegetation variation in the field being segmented into objects.

\subsection{Land Cover Changes}

Majority of land cover changes take place in the southern part of Kutai Barat, while only small areas in the northern parts experiencing changes during the last 20 years (Figure 8).

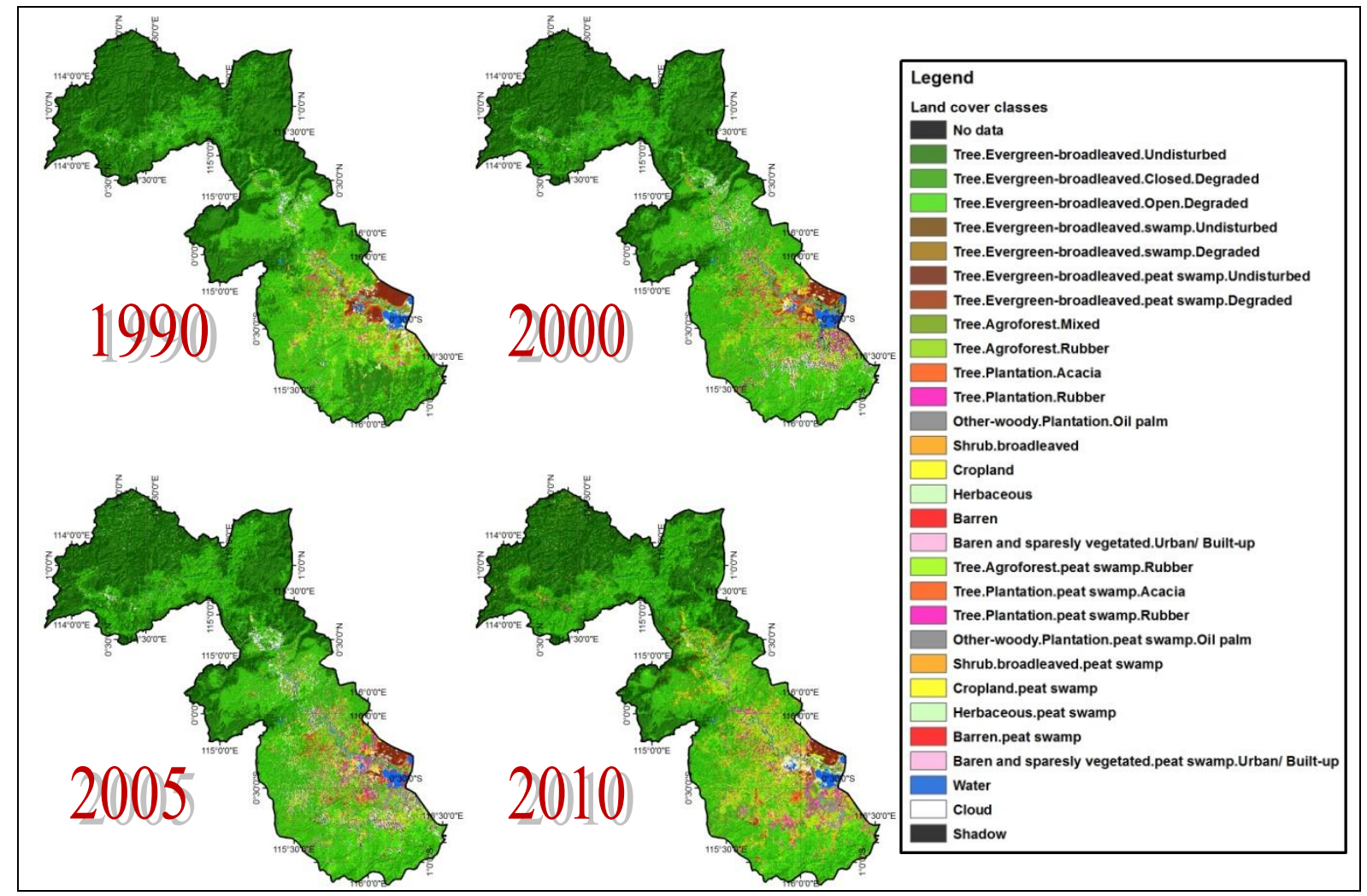

Figure 8. Land cover maps 1990, 2000, 2005 and 2010 of Kutai Barat

In the beginning of the observation period (1990), the undisturbed forest type of Tree.Evergreenbroadleaved in mineral soils area was the largest Land-Cover, occupying a total area of $1.6 \mathrm{M}$ ha, which is about $50 \%$ of the district area. However, it persistently decreased in the last two decades, with an area of 1.24 M ha in 2000, 1.1 M Ha in 2005 and $952000 \mathrm{Ha}$ in 2010. In other words, at the end of the observation period in 2010, this Land-Cover type had decreased to about $42 \%$ of its initial area, either deforested or degraded by 2010. In the same period, other Land-Cover types that decreased substantially in 1990-2010 were undisturbed and degraded Tree.Evergreen-broadleaved in the swamp area. The total area of these Land-Cover classes in 1990 was 74292 ha and $65 \%$ of it 
changed into other Land-Cover types with the remaining area of these classes being 26000 ha in 2010. The undisturbed and degraded Tree.Evergreen-broadleaved in the peat swamp area also decreased by $44 \%$ from 28271 ha in 1990 , to 15832 ha in 2010 .

The closed-degraded and open-degraded types of Tree.Evergreen-broadleaved in mineral soils area increased constantly from the total area of 1.1 M Ha in 1990 to only 1.5 M Ha in 2010. Substantial increase in the area also occurred due to shrub-dominated lands and oil palm plantations which increased approximately five times (400-560\%) from 1990 to 2010. Similarly, the areas of agroforests and rubber monocultures increased from $2.2 \%$ to $4.4 \%$ and $0.5 \%$ to $1.2 \%$ of the district area, respectively. Changes in Land-Cover areas can be seen in more detail in Figure 9 and Table 2 below.

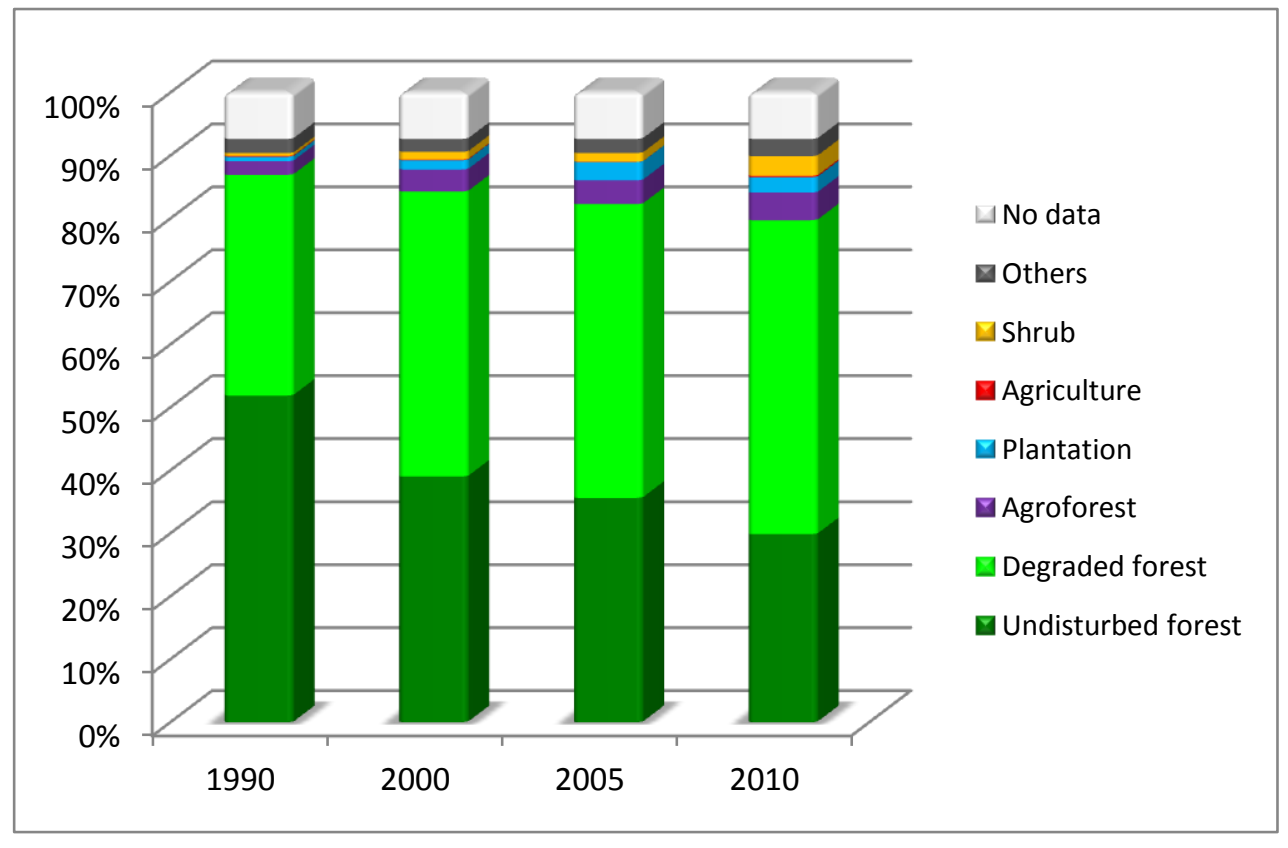

Figure 9. Land cover changes of Kutai Barat 1990-2010 
Table 2. Land cover changes in Kutai Barat 1990-2010 (in hectares)

\begin{tabular}{|c|c|c|c|c|}
\hline I-REDD Land cover classes & 1990 & 2000 & 2005 & 2010 \\
\hline Tree.Evergreen-broadleaved.Undisturbed & $1,646,258$ & $1,241,547$ & $1,139,017$ & 952,043 \\
\hline Tree.Evergreen-broadleaved.Closed.Degraded & 988,876 & $1,263,943$ & $1,291,643$ & $1,347,074$ \\
\hline Tree.Evergreen-broadleaved.Open.Degraded & 108,666 & 182,032 & 221,142 & 277,589 \\
\hline Tree.Evergreen-broadleaved.swamp.Undisturbed & 29,404 & 22,389 & 13,557 & 13,148 \\
\hline Tree.Evergreen-broadleaved.swamp.Degraded & 44,888 & 33,585 & 18,193 & 13,116 \\
\hline Tree.Evergreen-broadleaved.peat swamp.Undisturbed & 36,480 & 24,210 & 23,169 & 20,808 \\
\hline Tree.Evergreen-broadleaved.peat swamp.Degraded & 14,269 & 14,031 & 8,789 & 7,463 \\
\hline Tree.Agroforest.Mixed & 13,769 & 42,484 & 54,260 & 11,768 \\
\hline Tree.Agroforest.Rubber & 57,169 & 70,590 & 67,611 & 115,009 \\
\hline Tree.Plantation.Acacia & 83 & 1,392 & 4,735 & 5,424 \\
\hline Tree.Plantation.Rubber & 16,940 & 30,241 & 42,133 & 38,709 \\
\hline Other-woody.Plantation.Oil palm & 6,100 & 15,305 & 41,184 & 49,014 \\
\hline Shrub.broadleaved & 14,495 & 32,762 & 37,567 & 92,963 \\
\hline Cropland & 3,904 & 2,745 & 873 & 6,175 \\
\hline Herbaceous & 19,672 & 3,254 & 1,151 & 20,268 \\
\hline Shrub/Herb/Barren & 7,930 & 13,799 & 19,610 & 12,437 \\
\hline Baren and sparesly vegetated.Urban/ Built-up & 574 & 2,660 & 6,039 & 3,981 \\
\hline Tree.Agroforest.Peat swamp.Rubber & 595 & 2,126 & 2,712 & 3,836 \\
\hline Tree.Plantation.Peat swamp.Acacia & 0 & 12 & 381 & 14 \\
\hline Tree.Plantation.Peat swamp.Rubber & 344 & 1,106 & 3,219 & 2,038 \\
\hline Other-woody.Plantation.Peat swamp.Oil palm & 33 & 841 & 4,589 & 6,707 \\
\hline Shrub.broadleaved.Peat swamp & 307 & 7,852 & 8,372 & 6,037 \\
\hline Cropland.Peat swamp & 5 & 119 & 0 & 202 \\
\hline Herbaceous.Peat swamp & 4,468 & 5,666 & 4,549 & 8,690 \\
\hline Shrub/Herb/Barren.Peat swamp & 293 & 829 & 382 & 323 \\
\hline Baren and sparesly vegetated.Peat swamp.Urban/ Built-up. & 16 & 19 & 648 & 693 \\
\hline Water & 41,977 & 41,977 & 41,988 & 41,988 \\
\hline No data & 242,589 & 242,589 & 242,589 & 242589 \\
\hline Grand total & 3300104 & 3300104 & 3300104 & 3300104 \\
\hline
\end{tabular}




\subsection{Deforestation and forest degradation}

The reclassification of land cover classes into undisturbed forest, degraded forest and other land cover types are shown in Table 3 below.

Table 3. Reclassification of land cover classes into forest cover classes

\begin{tabular}{|c|c|c|c|c|c|}
\hline I-REDD Land cover classes & $\begin{array}{l}\text { Forest cover } \\
\text { classes }\end{array}$ & 1990 & 2000 & 2005 & 2010 \\
\hline $\begin{array}{l}\text { Tree.Evergreen- } \\
\text { broadleaved.Undisturbed }\end{array}$ & Undisturbed Forest & 1646258 & 1241547 & 1139017 & 952043 \\
\hline $\begin{array}{l}\text { Tree.Evergreen- } \\
\text { broadleaved.Closed.Degraded }\end{array}$ & Degraded Forest & 988876 & 1263943 & 1291643 & 1347074 \\
\hline $\begin{array}{l}\text { Tree.Evergreen- } \\
\text { broadleaved.Open.Degraded }\end{array}$ & Degraded Forest & 108666 & 182032 & 221142 & 277589 \\
\hline $\begin{array}{l}\text { Tree.Evergreen- } \\
\text { broadleaved.Swamp.Undisturbed }\end{array}$ & Undisturbed Forest & 29404 & 22389 & 13557 & 13148 \\
\hline $\begin{array}{l}\text { Tree.Evergreen- } \\
\text { broadleaved.Swamp.Degraded }\end{array}$ & Degraded Forest & 44888 & 33585 & 18193 & 13116 \\
\hline $\begin{array}{l}\text { Tree.Evergreen-broadleaved.Peat } \\
\text { swamp.Undisturbed }\end{array}$ & Undisturbed Forest & 36480 & 24210 & 23169 & 20808 \\
\hline $\begin{array}{l}\text { Tree.Evergreen-broadleaved.Peat } \\
\text { swamp.Degraded }\end{array}$ & Degraded Forest & 14269 & 14031 & 8789 & 7463 \\
\hline \multicolumn{2}{|l|}{ Forest in total } & 2868842 & 2781738 & 2715511 & 2631240 \\
\hline Other land cover classes & Non-forest & 188673 & 275777 & 342004 & 426274 \\
\hline No data & No data & 242589 & 242589 & 242589 & 242589 \\
\hline Grand Total & & 3300104 & 3300104 & 3300104 & 3300104 \\
\hline
\end{tabular}

During the period of 1990-2010, the total forest area decreased from $2.86 \mathrm{M}$ ha (87\% of total district area) to $2.78 \mathrm{M}$ ha (84\%), $2.71 \mathrm{M}$ ha $(82 \%), 2.63 \mathrm{M}$ ha $(80 \%)$. Thus, in the last 20 years, the loss of forest in Kutai Barat was approximately $8 \%$ of the initial forest area in 1990. In average, forest area loss in the three change periods were 8710 ha per year in 1990-2000, 13245 ha per year (2000-2005), and 16854 ha per year (2005-2010). The proportion of undisturbed forest, degraded forest and nonforest of Kutai Barat during 1990-2010 is shown in Figure 10. 


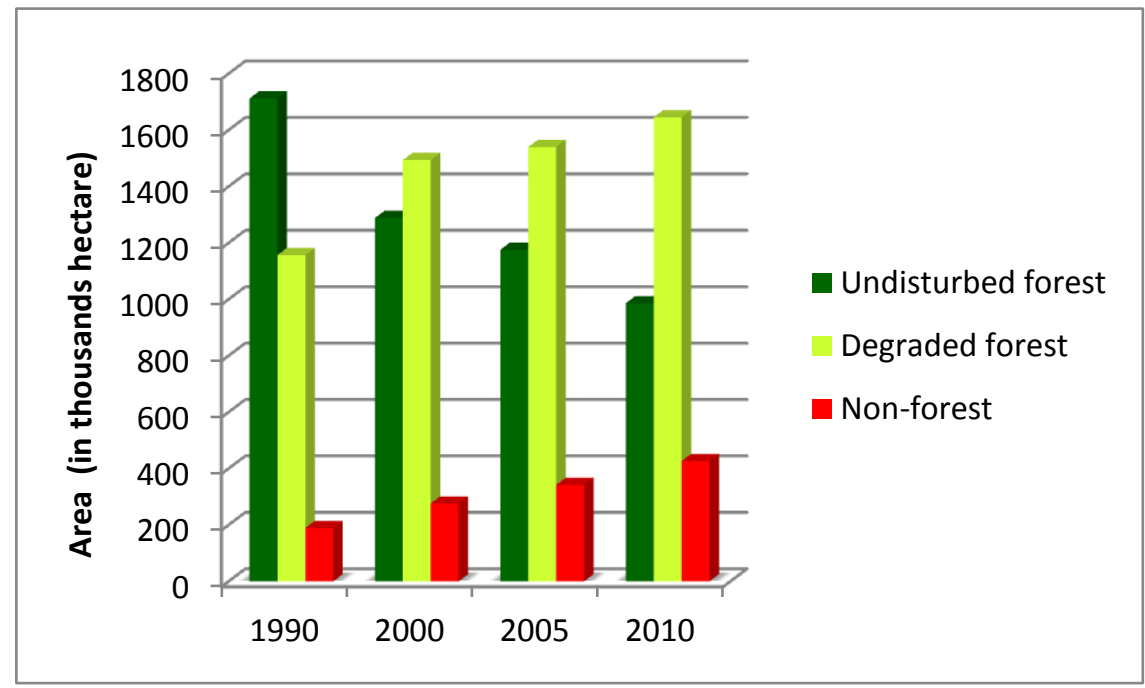

Figure 10. Proportion of undisturbed forest, degraded forest and non-forest of Kutai Barat 1990-2010

Forest degradation in the period of 1990-2000 reached 411833 Ha with an average area increase of degradation 41183 Ha per year. During 2000-2005, forest degradation decreased to $110689 \mathrm{Ha}$, or an average of 22138 Ha per year. In 2005-2010 forest degradation increased again to $178900 \mathrm{Ha}$, or 35 780 Ha per year. Deforestation and forest degradation maps of Kutai Barat during 1990-2000, 20002005 and 2005-2010 can be seen in Figure 11. 

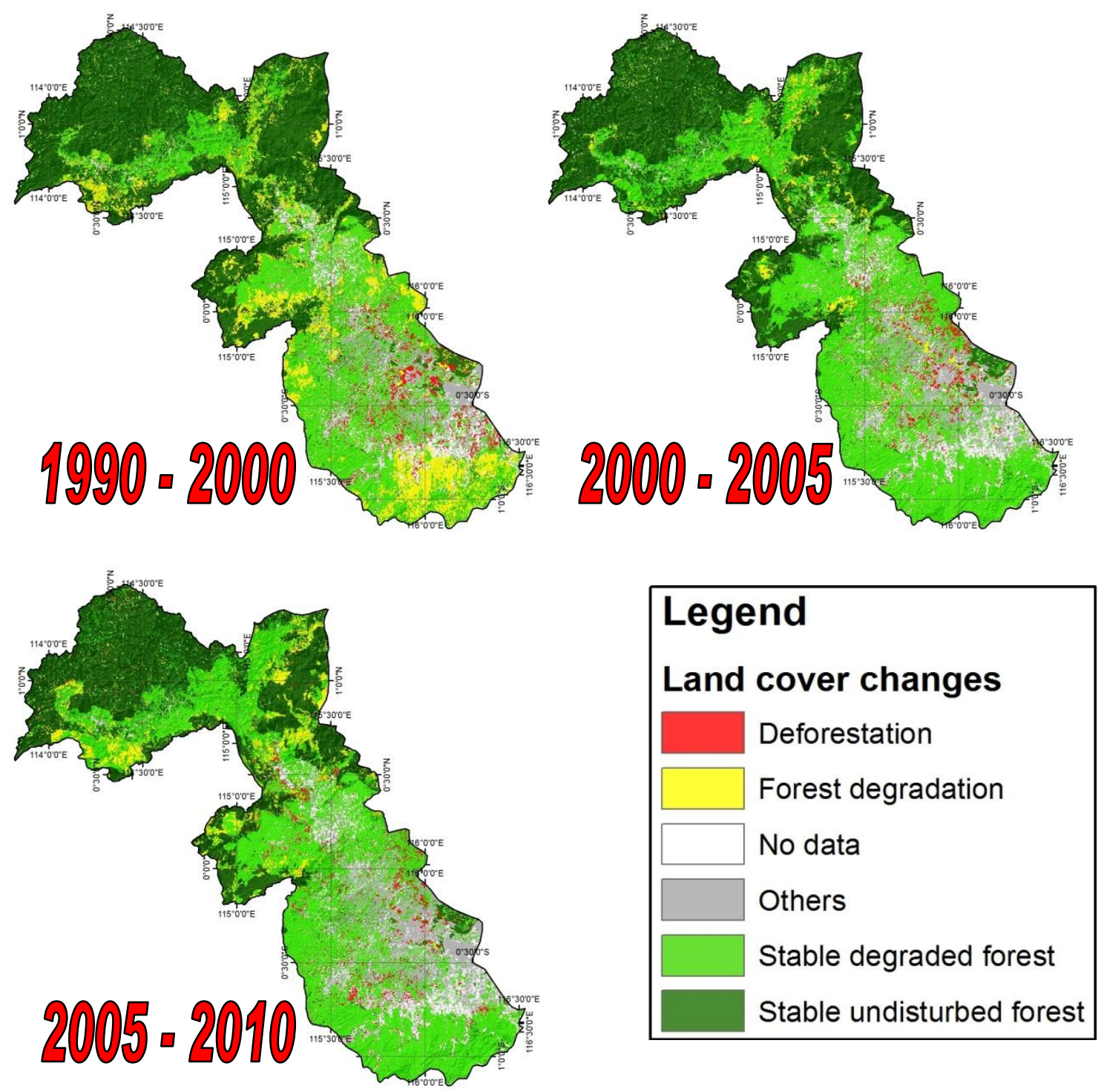

Figure 11. Deforestation and forest degradation maps of Kutai Barat

\subsection{Deforestation and forest conversion}

The annual rates of deforestation in Kutai Barat for the three periods are 0.31\% (1990-2000), $0.48 \%$ (2000-2005) and $0.63 \%$ (2005-2010). Large areas of forest loss took place in the areas classified as non forest land (APL) and Production Forest (HP). Nevertheless, despite the smaller areas, forest loss and conversions also occurred inside the Protection Forest with the amount of 1.89 ha per year in 1990-2000, 27.8 ha per year (2000-2005) and 863.4 ha per year (2005-2010).

Deforestation occurrence based on forest land designation in Kutai Barat during 1990-2010 is shown in Figure 12. 


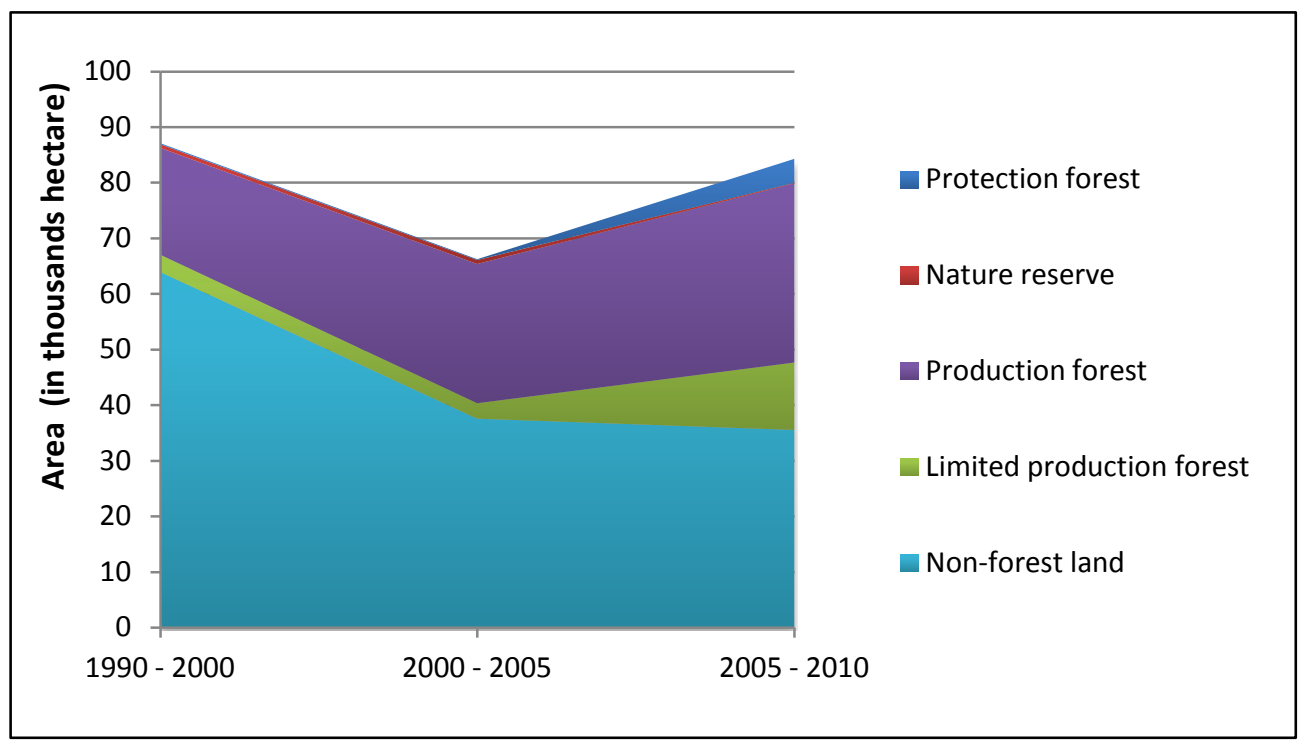

Figure 12. Deforestation occurrence based on forest land designation in Kutai Barat during 1990-2010

On the major trajectories of forest loss in 1990-2000, the largest area was shown by changes from forest to agroforest and to shrub, which contributed to $43 \%$ and 23\% of total forest loss area of 87104 ha in 1990-2000 (Figure 13). In addition, forest was also converted to plantations (21\%) and, to a much smaller extent, to agriculture (1\%).

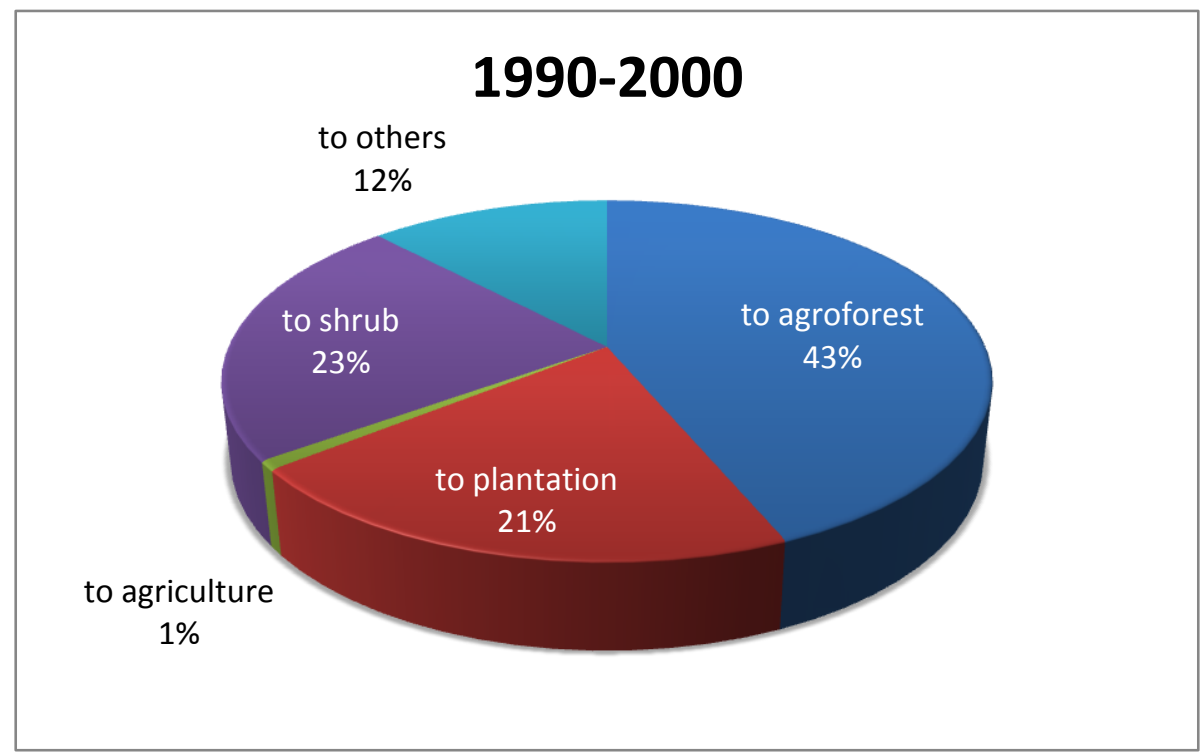

Figure 13. Trajectories of forest conversions for 1990-2000

For the forest loss in 2000-2005 (66 227 ha), the major trajectories shared 40\% and 42\% contributions as changes from forest to agroforest and to plantation (Figure 14). 


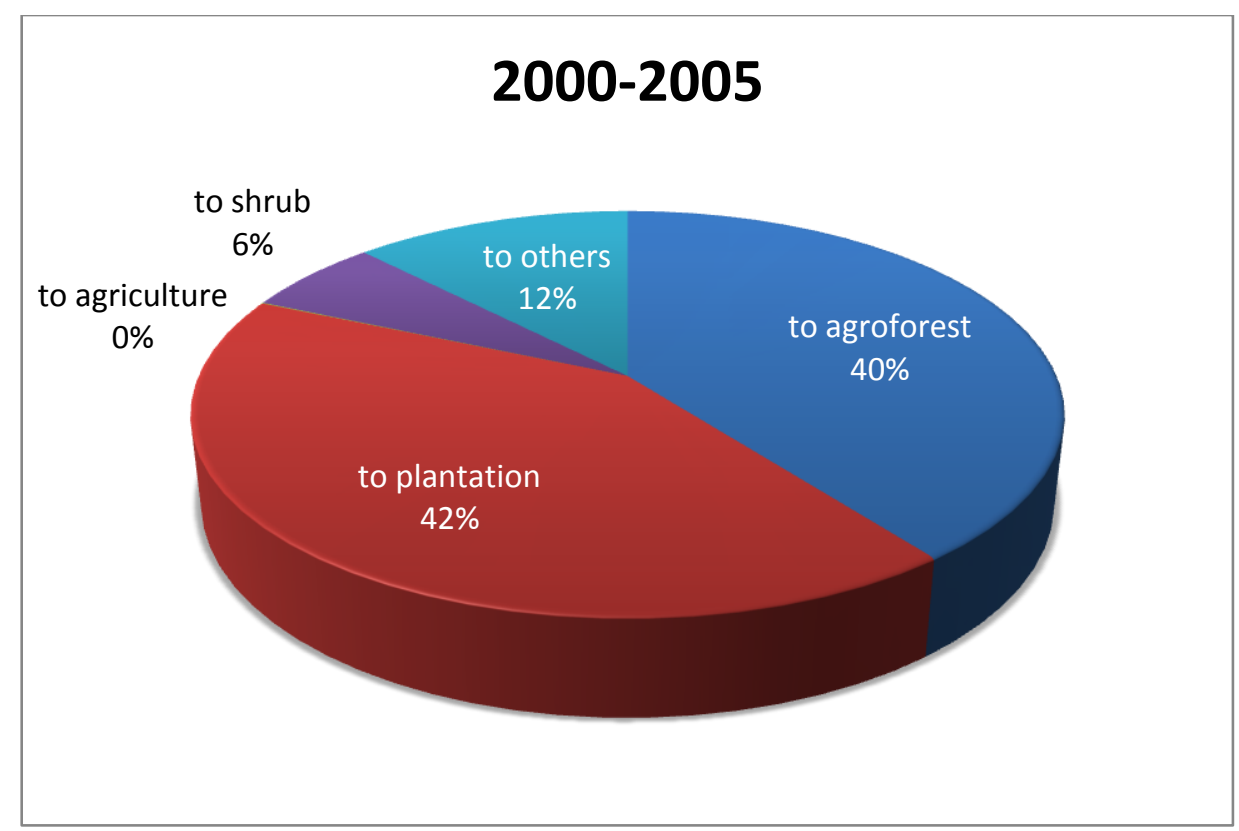

Figure 14. Trajectories of forest conversions for 2000-2005

In 2005-2010, the largest trajectories were changes from forest to agroforests and to shrubs, which contributed $36 \%$ and $31 \%$ of forest loss area of 84271 ha (Figure 15).

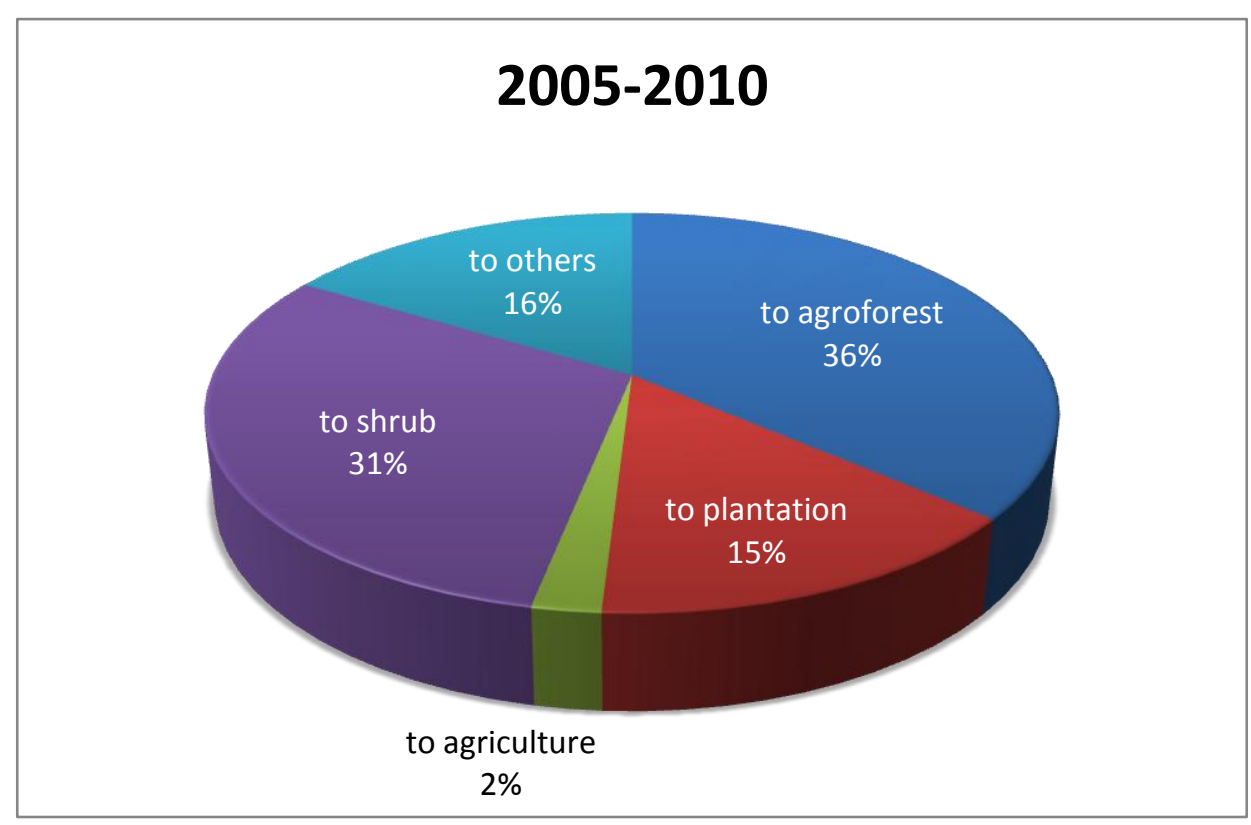

Figure 15. Trajectories of forest conversions for 2005-2010 


\subsection{Forest degradation}

The annual rates of forest degradation in Kutai Barat for the three periods were 2.74\% (1990-2000), $1.78 \%$ (2000-2005), and 3.28\% (2005-2010). Most of the forest degradation occurred in areas designated as Production Forest (HP) and Limited Production Forest (HPT). Nevertheless, forest degradation also occurred largely in Protection Forests was an average of 6611 Ha per year in 19902000, 5961 Ha per year (2000-2005) and 11555 Ha per year (2005-2010).

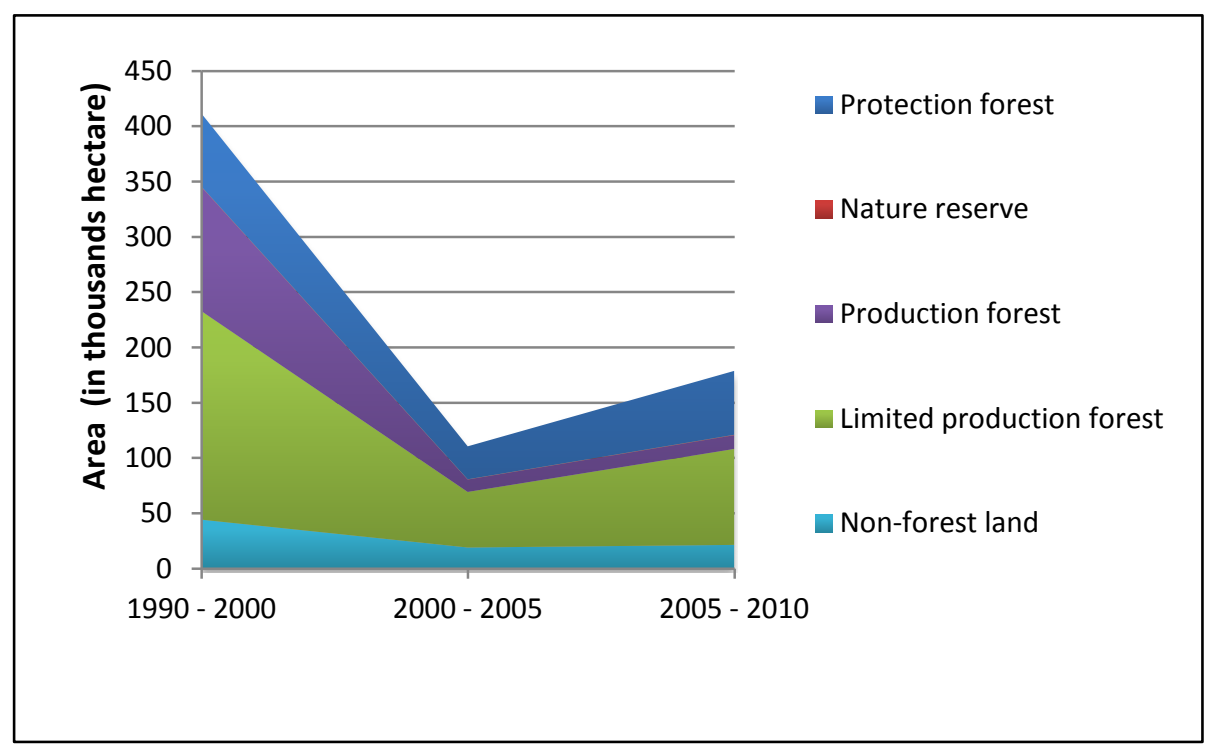

Figure 16. Forest degradation based on forest land designation in Kutai Barat during 1990-2010

\section{Discussions}

Between 1990 and 2010, deforestation in Kutai Barat took place largely in the areas categorized as Non-forest Land (APL) and Production Forest (HP). For APL areas, forest conversions are indeed legal, where the forest is extracted of its resources and the lands were developed for the interests of economic development and other production and livelihood needs. In the Production Forest areas, forest timber extraction is legal, although conversions for agricultural commodities are not, unless the forest land status is transformed into another status where conversions are allowed.

The study found that most of forest loss in Kutai Barat during 1990 - 2010 was caused by changes from degraded forest (especially open and closed Tree.Evergreen-broadleaved) to rubber agroforests, rubber plantations and shrub land. Anecdotal information showed that the increase of rubber agroforests and rubber plantations, which are mostly developed by local communities, might be driven, or at least supported, by government programs of providing rubber seeds to communities. This Land-Use development mostly takes place in the non-state forest land (APL) areas, and thus is inevitable for the economic development, population growth and people's livelihood. Changes to shrub land normally refer to effects of logging concessions which leave the land with secondary 
regrowth. The constant increase of shrubland for 1990-2010, should alarm the district stakeholders in managing the lands to improve their livelihoods and the environment.

Similar to deforestation, most of the forest degradation occurred in the area designated as Production Forest and Limited Production Forest where tree cutting is legal, as long as the logging companies hold concession permits from the Ministry of Forestry and the local government. However, to reduce logging impacts to the environment, it is imperative that the companies obey and implement regulations that promote sustainable forest management (e.g. not exceeding annual logging quotas, conducting land rehabilitation and replanting after logging, protecting high conservation value areas). Aligned with such enforcements, the Ministry of Forestry and the local government, as regulator bodies, should conduct monitoring and evaluation efforts to make sure that forest management practices are implemented properly.

Forest degradation in Kutai Barat occurred not only in Production Forest areas, but also in Protection Forest, where logging is illegal, but nonetheless showed a steady increase of degradation throughout the study period. This practice occurs mostly around the forest boundaries and is most likely due to the adjacency of the Protection Forest with logging concession areas and/or villages. The reason might be due to unclear boundaries, while in some instances illegal logging might be done deliberately. In the core zone of Protection Forests with less accessibility, forest degradation is very low. 


\section{Conclusion/recommendations}

Forest deforestation and degradation in Kutai Barat mostly took place in the southern parts of the district, where according to the land designation, some of them are legal (and necessary) while some are illegal. In answer to the illegal, the role of forest monitoring and law enforcement is key, and it should be reinforced optimally, while alternative livelihood options for communities living around the forest should also be promoted in order to reduce encroachments in the protection areas.

For a district where natural resources still play a major role in the development and economic growth, strategies on Land-Use planning and its implementation, which accommodate environmental protection and community development, should be comprehensively designed in order to ensure good environmental practices as well as to improve community livelihood. This latter notion should be well captured in the various strategies to mitigate climate change such as REDD+ and Land-Use planning for low $\left(\mathrm{CO}_{2}\right)$ emission development. 


\section{Appendix}

\subsection{Appendix 1. Description of land cover classes}

\begin{tabular}{cll}
\hline No & I-REDD LC classes (ICRAF) & Descriptions \\
\hline $1 \quad \begin{array}{l}\text { Tree.Evergreen- } \\
\text { broadleaved.Undisturbed }\end{array}$ & $\begin{array}{l}\text { Undisturbed forest is natural forest cover with a dense canopy, highly diverse } \\
\text { species of trees and basal areas. It has no logging roads, indicating that it has } \\
\text { never been logged, at least not on a large scale, and is usually located in areas with } \\
\text { a rough topography. Canopy cover of undisturbed forest is usually }>80 \% . \text { In satellite } \\
\text { images it is indicated by high value of vegetation index and infrared spectrum } \\
\text { channels and lower value in visible spectrum channels. }\end{array}$ \\
\hline
\end{tabular}

2 Tree.Evergreenbroadleaved.Closed.Degraded

3 Tree.Evergreenbroadleaved.Open.Degraded
Natural forest area having been disturbed by logging, or other timber extraction activities, or fire but still has a relatively dense tree cover and dense canopy. Canopy cover is around $20-60 \%$. Large trees with diameter $>30 \mathrm{~cm}$ may still be found.
Natural forest area having been disturbed by logging or other timber extraction activities, or fire, but already has relatively rare tree cover and rare canopy. Large trees with diameter $>30 \mathrm{~cm}$ cannot be found.
4 Tree.Evergreenbroadleaved.swamp.Undisturbed
Similar to no.1, but located in swampy areas and generally with lower vegetation size / shorter and lower density than lowland forests and forests in the mountainous region.
5 Tree.Evergreenbroadleaved.swamp.Degraded
Similar to No. 3, but is located in a swampy area.

A swamp forest is a wetland featuring temporary or permanent inundation of large areas of land by shallow bodies of water with natural vegetation cover, has never been logged in the past and has also not been degraded or affected by any human activities.

7 Tree.Evergreen-broadleaved.peat Logged-over swamp forest is swamp with natural forest cover that has been logged swamp.Degraded or degraded.

8 Tree.Agroforest.Mixed Mixed garden is an agroforest or tree-based system with more than $30 \%$ of the area consisting of various species of trees. Mixed garden is usually located in $0.5-1 \mathrm{~km}$ distance to settlement or road.

9 Tree.Agroforest.Rubber

Rubber agroforest is characterized by the presence of rubber trees mixed with other tree species and shrub, which form a stand structure similar to secondary forest. Rubber trees usually account for less than $70 \%$ of the population of trees above 10 $\mathrm{cm} \mathrm{dbh}$. When the presence of non-rubber trees is dominant, and the plot is old enough, the area will be very hard to differentiate from a natural forest.

\begin{tabular}{lll}
\hline 10 & Tree.Plantation.Acacia & Monoculture plantation of acacia. \\
\hline 11 & Tree.Plantation.Rubber & Monoculture plantation of rubber, usually has a spacing by $3 \times 3 \mathrm{~m}$. \\
\hline 12 & Other-woody.Plantation.Oil palm & $\begin{array}{l}\text { Monoculture plantation of oil palm planted by private companies and local } \\
\text { communities. }\end{array}$ \\
\hline 13 & Shrub.broadleaved & $\begin{array}{l}\text { Area dominated by non-woody vegetation, which is usually a former forest clearing } \\
\text { area undergoing natural secondary regrowth. For old shrubs, there is a low cover of } \\
\text { trees, around } 5 \% \text { cover; but no trees with a diameter }>20 \mathrm{~cm} .\end{array}$ \\
\hline 14 & Cropland & $\begin{array}{l}\text { Area used to grow crops other than rice. For example: potato, chili, cabbage, maize } \\
\text { and etc. }\end{array}$ \\
\hline 15 & Herbaceous & Area dominated by grass, usually an abandoned area. \\
\hline
\end{tabular}


No

16 Shrub/Herb/Barren

\section{Descriptions}

Area where trees have been cleared, which includes ex-logging areas or slashedand-burned areas prepared for agriculture; vegetation cover is usually herbaceous vegetation and/or grass.

Settlement refers to built area (city or village), which includes road; main road and/or logging road; for rural settlement this includes home gardens immediately located near the houses.

Similar to no. 9 , but in a peat area.

18 Tree.Agroforest.peat swamp.Rubber

\begin{tabular}{|c|c|c|}
\hline 19 & $\begin{array}{l}\text { Tree.Plantation.peat } \\
\text { swamp.Acacia }\end{array}$ & Similar to no. 10 , but in a peat area \\
\hline 20 & $\begin{array}{l}\text { Tree.Plantation.peat } \\
\text { swamp.Rubber }\end{array}$ & Similar to no. 11 , but in a peat area. \\
\hline 21 & $\begin{array}{l}\text { Other-woody.Plantation.peat } \\
\text { swamp.Oil palm }\end{array}$ & Similar to no. 12 , but in a peat area. \\
\hline 22 & Shrub.broadleaved.peat swamp & Similar to no. 13 , but in a peat area. \\
\hline 23 & Cropland.peat swamp & Similar to no. 14 , but in a peat area. \\
\hline 24 & Herbaceous.peat swamp & Similar to no. 15 , but in a peat area. \\
\hline 25 & Shrub/Herb/Barren.peat swamp & Similar to no. 16 , but in a peat area. \\
\hline 26 & $\begin{array}{l}\text { Baren and sparesly } \\
\text { vegetated.peat swamp.Urban/ } \\
\text { Built-up }\end{array}$ & Similar to no. 17 , but in a peat area. \\
\hline 27 & Water & Water body refers to an area covered with water, for example: stream, lake, pond. \\
\hline
\end{tabular}




\subsection{Appendix 2. Error matrix of land cover map 2010}

\begin{tabular}{|c|c|c|c|c|c|c|c|c|c|c|c|c|c|c|c|c|c|}
\hline $\begin{array}{l}\text { Classification data } \backslash \\
\text { Reference data }\end{array}$ & 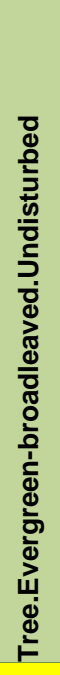 & 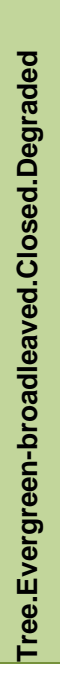 & 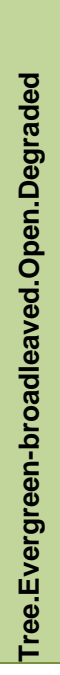 & 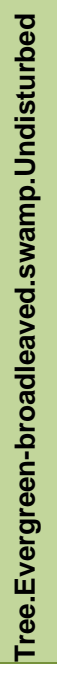 & 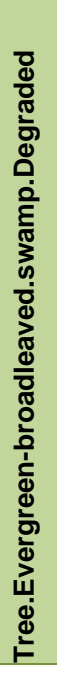 & 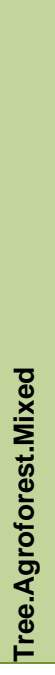 & 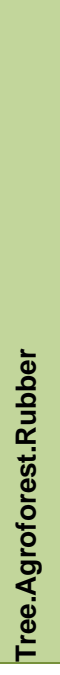 & 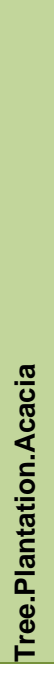 & 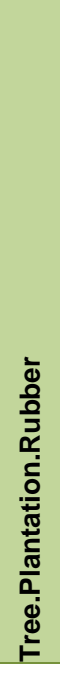 & 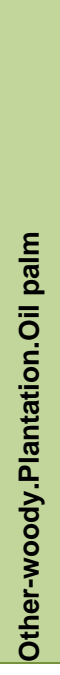 & 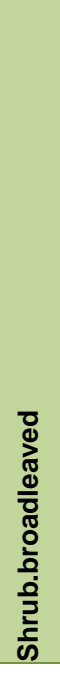 & $\begin{array}{l}\frac{0}{\frac{2}{0}} \\
\frac{\pi}{0} \\
\frac{0}{0} \\
\frac{1}{0}\end{array}$ & 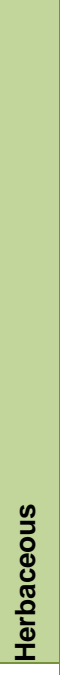 & 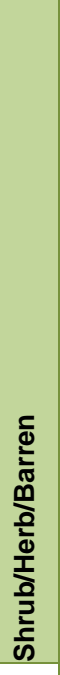 & 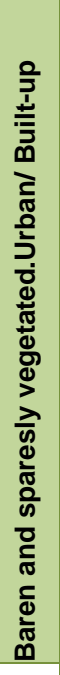 & 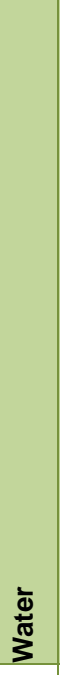 & 焉 \\
\hline $\begin{array}{l}\text { Tree.Evergreen- } \\
\text { broadleaved.Undisturbed }\end{array}$ & 0 & 0 & 0 & 0 & 0 & 0 & 0 & 0 & 0 & 0 & 1 & 0 & 0 & 0 & 0 & 0 & 1 \\
\hline $\begin{array}{l}\text { Tree.Evergreen- } \\
\text { broadleaved.Closed.Degraded }\end{array}$ & 0 & 44 & 3 & 0 & 0 & 0 & 5 & 0 & 1 & 1 & 12 & 0 & 0 & 0 & 0 & 0 & 66 \\
\hline $\begin{array}{l}\text { Tree.Evergreen- } \\
\text { broadleaved.Open.Degraded }\end{array}$ & 0 & 2 & 24 & 0 & 0 & 1 & 2 & 0 & 1 & 2 & 5 & 0 & 0 & 0 & 0 & 0 & 37 \\
\hline $\begin{array}{l}\text { Tree.Evergreen- } \\
\text { broadleaved.swamp.Undisturbed }\end{array}$ & 0 & 1 & 0 & 0 & 0 & 0 & 0 & 0 & 0 & 0 & 0 & 0 & 0 & 0 & 0 & 0 & 1 \\
\hline $\begin{array}{l}\text { Tree.Evergreen- } \\
\text { broadleaved.swamp.Degraded }\end{array}$ & 0 & 1 & 1 & 0 & 2 & 0 & 0 & 0 & 0 & 0 & 0 & 0 & 0 & 0 & 0 & 0 & 4 \\
\hline Tree.Agroforest.Mixed & 0 & 0 & 1 & 0 & 0 & 2 & 0 & 0 & 1 & 0 & 0 & 0 & 0 & 0 & 0 & 0 & 4 \\
\hline Tree.Agroforest.Rubber & 0 & 1 & 0 & 0 & 0 & 0 & 34 & 0 & 6 & 1 & 1 & 0 & 0 & 2 & 0 & 0 & 45 \\
\hline Tree.Plantation.Acacia & 0 & 0 & 0 & 0 & 0 & 0 & 0 & 3 & 0 & 0 & 1 & 0 & 0 & 0 & 0 & 0 & 4 \\
\hline Tree.Plantation.Rubber & 0 & 0 & 0 & 0 & 0 & 0 & 2 & 0 & 19 & 0 & 1 & 0 & 0 & 0 & 0 & 0 & 22 \\
\hline Other-woody.Plantation.Oil palm & 0 & 0 & 0 & 0 & 0 & 0 & 2 & 0 & 0 & 25 & 0 & 0 & 0 & 0 & 3 & 0 & 30 \\
\hline Shrub.broadleaved & 0 & 0 & 0 & 0 & 0 & 0 & 1 & 0 & 4 & 0 & 45 & 0 & 1 & 1 & 1 & 1 & 54 \\
\hline Cropland & 0 & 0 & 0 & 0 & 0 & 0 & 0 & 0 & 0 & 0 & 0 & 2 & 0 & 0 & 0 & 0 & 2 \\
\hline Herbaceous & 0 & 0 & 0 & 0 & 0 & 0 & 0 & 0 & 0 & 1 & 1 & 0 & 16 & 0 & 2 & 1 & 21 \\
\hline Shrub/Herb/Barren & 0 & 0 & 0 & 0 & 0 & 0 & 0 & 0 & 0 & 0 & 0 & 0 & 0 & 4 & 0 & 0 & 4 \\
\hline $\begin{array}{l}\text { Baren\&sparesly } \\
\text { vegetated.Urban/Built-up }\end{array}$ & 0 & 0 & 0 & 0 & 0 & 0 & 0 & 0 & 0 & 0 & 0 & 0 & 0 & 0 & 15 & 0 & 15 \\
\hline Water & 0 & 0 & 0 & 0 & 0 & 0 & 0 & 0 & 0 & 0 & 0 & 0 & 0 & 0 & 0 & 4 & 4 \\
\hline Total & 0 & 49 & 29 & 0 & 2 & 3 & 46 & 3 & 32 & 30 & 67 & 2 & 17 & 7 & 21 & 6 & 314 \\
\hline
\end{tabular}




\subsection{Appendix 3. Accuracy of each land cover category in land cover map}

2010

\begin{tabular}{|c|c|c|c|}
\hline Land cover classes & $\begin{array}{l}\text { Correctly classified } \\
\text { pixels in map }\end{array}$ & $\begin{array}{l}\text { GPS points } \\
\text { from the field }\end{array}$ & $\begin{array}{c}\text { Accuracy } \\
\text { Assessment (\%) }\end{array}$ \\
\hline Tree.Evergreen-broadleaved.Closed.Degraded & 44 & 49 & $89.80 \%$ \\
\hline Tree.Evergreen-broadleaved.Open.Degraded & 24 & 29 & $82.76 \%$ \\
\hline Tree.Evergreen-broadleaved.swamp.Degraded & 2 & 2 & $100.00 \%$ \\
\hline Tree.Agroforest.Mixed & 2 & 3 & $66.67 \%$ \\
\hline Tree.Agroforest.Rubber & 34 & 46 & $73.91 \%$ \\
\hline Tree.Plantation.Acacia & 3 & 3 & $100.00 \%$ \\
\hline Tree.Plantation.Rubber & 19 & 32 & $59.38 \%$ \\
\hline Other-woody.Plantation.Oil palm & 25 & 30 & $83.33 \%$ \\
\hline Shrub.broadleaved & 45 & 67 & $67.16 \%$ \\
\hline Cropland & 2 & 2 & $100.00 \%$ \\
\hline Herbaceous & 16 & 17 & $94.12 \%$ \\
\hline Shrub/Herb/Barren & 4 & 7 & $57.14 \%$ \\
\hline $\begin{array}{l}\text { Baren and sparesly vegetated.Urban/ } \\
\text { Built-up }\end{array}$ & 15 & 21 & $71.43 \%$ \\
\hline Water & 4 & 6 & $66.67 \%$ \\
\hline Total & 239 & 314 & $76.11 \%$ \\
\hline
\end{tabular}




\section{References}

Blumberg D and Zhu G. 2007. Using a hierarchical multi-resolution mechanism for the classification and semantic extraction of landuse maps for Beer-Sheva, Israel. International Journal of Remote Sensing, 28(15), 3273-3289.

Budiman A, Nguyen Ha, Heiniman A, Hett C, Hostert P, Huafang C, Thi Thu HN, An NT, Pflugmacher D, Schmidt-Vogt D, Bang TN, Widayati A. 2012. Landscape scale maps and statistics of forest cover and other relevant land uses for I-REDD+ study sites. Project report. IREDD+. Project no. 265286.

Dewi S, Johana F, Ekadinata A and Agung P. 2013. Land-use planning for low emission development strategies (LUWES). ASB Policy brief 35. Nairobi. ASB Partnership for the tropical Forest Margins.

Dewi S and Ekadinata A. 2010. Analysis of Land use and cover trajectories (ALUCT). Bogor, Indonesia. World Agroforestry Centre (ICRAF), SEA regional office.

Di Gregorio A and Jansen Louisa JM. 2005. Land Cover Classification System (LCCS): Classification concepts and user manual for software version 2.0. FAO, Rome. ISBN: 92-5$105327-8$

Ekadinata A, Widayati A, Dewi S, Rahman S, van Noordwijk M. 2011. Indonesia's land use and land cover changes and their trajectories (1990, 2000 and 2005). ALLREDDI Brief 01. Bogor, Indonesia: World Agroforestry Centre (ICRAF) Southeast Asia Regional Program.

FAO. 1995. Forest resources assessment 1990. Global Synthesis. FAO, Rome.

FAO. 2010. Global forest resources assessment 2010: terms and definitions. Rome, Italy.

Morton DC, Sales Marcio H, Souza Jr Carlos M and Griscom Bronson. 2011. Historic emission from deforestation and forest degradation in Mato Grosso, Brazil: 1) source data uncertanties. Carbon Balance and Management 6:18. doi: 10.1186/1750-0680-6-18

Puyravaud, Jean-Philippe. 2003. Standardardizing the calculation of the annual rate of deforestation. Forest Ecology and Management. ISSN 0378-1127. http://dx.doi.org/10.1016/S0378$\underline{1127(02) 00335-3}$

Richter R, Schlapfer D. 2013. ATCOR 2/3 user guide, version 8.2.1. Rese aplications Schalpser. Switzerland

Riedel T, Thiel C, Schmullius C. 2008. Fusion of multispectral optical and SAR images towards operational land cover mapping in Central Europe. In: T. Blaschke, S. Lang \& G. Hay (eds.): Object-sBased Image Analysis - Spatial concepts for knowledge-driven remote sensing applications. Berlin: Springer 493-512.

van der Werf GR, Morton DC, DeFries RS, Oliver JGJ, Kasibhatla P, Jackson RB, Collatz GJ, Randerson JT. 2009. C02 emissions from deforestation. Nature Geoscience, 2:737-738. 
Zulkarnain MT, Ekadinata A, Widayati A. 2013. Land cover mapping of Tanjung Jabung Barat, Jambi using Landsat - Alos Palsar data fusion and object-based hierarchical classification. 34th Asian Conference on Remote Sensing (ACRS). 2013. ISBN: 978-1-62993-910-0 



\section{WORKING PAPERS WITH DOIs}

2005

1. Agroforestry in the drylands of eastern Africa: a call to action

2. Biodiversity conservation through agroforestry: managing tree species diversity within a network of community-based, nongovernmental, governmental and research organizations in western Kenya.

3. Invasion of prosopis juliflora and local livelihoods: Case study from the Lake Baringo areaof Kenya

4. Leadership for change in farmers organizations: Training report: Ridar Hotel, Kampala, 29th March to 2nd April 2005.

5. Domestication des espèces agroforestières au Sahel : situation actuelle et perspectives

6. Relevé des données de biodiversité ligneuse: Manuel du projet biodiversité des parcs agroforestiers au Sahel

7. Improved land management in the Lake Victoria Basin: TransVic Project's draft report.

8. Livelihood capital, strategies and outcomes in the Taita hills of Kenya

9. Les espèces ligneuses et leurs usages: Les préférences des paysans dans le Cercle de Ségou, au Mali

10. La biodiversité des espèces ligneuses: Diversité arborée et unités de gestion du terroir dans le Cercle de Ségou, au Mali

2006

11. Bird diversity and land use on the slopes of Mt. Kilimanjaro and the adjacent plains, Tanzania

12. Water, women and local social organization in the Western Kenya Highlands

13. Highlights of ongoing research of the World Agroforestry Centre in Indonesia

14. Prospects of adoption of tree-based systems in a rural landscape and its likely impacts on carbon stocks and farmers' welfare: The FALLOW Model Application in Muara Sungkai, Lampung, Sumatra, in a 'Clean Development Mechanism' context

15. Equipping integrated natural resource managers for healthy Agroforestry landscapes.

17. Agro-biodiversity and CGIAR tree and forest science: approaches and examples from Sumatra.

18. Improving land management in eastern and southern Africa: A review of policies.

19. Farm and household economic study of Kecamatan Nanggung, Kabupaten Bogor, Indonesia: A socioeconomic base line study of Agroforestry innovations and livelihood enhancement.

20. Lessons from eastern Africa's unsustainable charcoal business.

21. Evolution of RELMA's approaches to land management: Lessons from two decades of research and development in eastern and southern Africa

22. Participatory watershed management: Lessons from RELMA's work with farmers in eastern Africa.

23. Strengthening farmers' organizations: The experience of RELMA and ULAMP.

24. Promoting rainwater harvesting in eastern and southern Africa.

25. The role of livestock in integrated land management.

26. Status of carbon sequestration projects in Africa: Potential benefits and challenges to scaling up.

27. Social and Environmental Trade-Offs in Tree Species Selection: A Methodology for Identifying Niche Incompatibilities in Agroforestry [Appears as AHI Working Paper no. 9]

28. Managing tradeoffs in agroforestry: From conflict to collaboration in natural resource management. [Appears as AHI Working Paper no. 10]

29. Essai d'analyse de la prise en compte des systemes agroforestiers pa les legislations forestieres au Sahel: Cas du Burkina Faso, du Mali, du Niger et du Senegal.

30. Etat de la recherche agroforestière au Rwanda etude bibliographique, période 1987-2003

2007

31. Science and technological innovations for improving soil fertility and management in Africa: A report for NEPAD's Science and Technology Forum.

32. Compensation and rewards for environmental services.

33. Latin American regional workshop report compensation.

34. Asia regional workshop on compensation ecosystem services. 
35. Report of African regional workshop on compensation ecosystem services.

36. Exploring the inter-linkages among and between compensation and rewards for ecosystem services CRES and human well-being

37. Criteria and indicators for environmental service compensation and reward mechanisms: realistic, voluntary, conditional and pro-poor

38. The conditions for effective mechanisms of compensation and rewards for environmental services.

39. Organization and governance for fostering Pro-Poor Compensation for Environmental Services.

40. How important are different types of compensation and reward mechanisms shaping poverty and ecosystem services across Africa, Asia \& Latin America over the Next two decades?

41. Risk mitigation in contract farming: The case of poultry, cotton, woodfuel and cereals in East Africa.

42. The RELMA savings and credit experiences: Sowing the seed of sustainability

43. Yatich J., Policy and institutional context for NRM in Kenya: Challenges and opportunities for Landcare.

44. Nina-Nina Adoung Nasional di So! Field test of rapid land tenure assessment (RATA) in the Batang Toru Watershed, North Sumatera.

45. Is Hutan Tanaman Rakyat a new paradigm in community based tree planting in Indonesia?

46. Socio-Economic aspects of brackish water aquaculture (Tambak) production in Nanggroe Aceh Darrusalam.

47. Farmer livelihoods in the humid forest and moist savannah zones of Cameroon.

48. Domestication, genre et vulnérabilité : Participation des femmes, des Jeunes et des catégories les plus pauvres à la domestication des arbres agroforestiers au Cameroun.

49. Land tenure and management in the districts around Mt Elgon: An assessment presented to the Mt Elgon ecosystem conservation programme.

50. The production and marketing of leaf meal from fodder shrubs in Tanga, Tanzania: A pro-poor enterprise for improving livestock productivity.

51. Buyers Perspective on Environmental Services (ES) and Commoditization as an approach to liberate ES markets in the Philippines.

52. Towards Towards community-driven conservation in southwest China: Reconciling state and local perceptions.

53. Biofuels in China: An Analysis of the Opportunities and Challenges of Jatropha curcas in Southwest China.

54. Jatropha curcas biodiesel production in Kenya: Economics and potential value chain development for smallholder farmers

55. Livelihoods and Forest Resources in Aceh and Nias for a Sustainable Forest Resource Management and Economic Progress

56. Agroforestry on the interface of Orangutan Conservation and Sustainable Livelihoods in Batang Toru, North Sumatra.

57. Assessing Hydrological Situation of Kapuas Hulu Basin, Kapuas Hulu Regency, West Kalimantan.

58. Assessing the Hydrological Situation of Talau Watershed, Belu Regency, East Nusa Tenggara.

59. Kajian Kondisi Hidrologis DAS Talau, Kabupaten Belu, Nusa Tenggara Timur.

60. Kajian Kondisi Hidrologis DAS Kapuas Hulu, Kabupaten Kapuas Hulu, Kalimantan Barat.

61. Lessons learned from community capacity building activities to support agroforest as sustainable economic alternatives in Batang Toru orang utan habitat conservation program (Martini, Endri et al.)

62. Mainstreaming Climate Change in the Philippines.

63. A Conjoint Analysis of Farmer Preferences for Community Forestry Contracts in the Sumber Jaya Watershed, Indonesia.

64. The highlands: a shared water tower in a changing climate and changing Asia

65. Eco-Certification: Can It Deliver Conservation and Development in the Tropics.

66. Designing ecological and biodiversity sampling strategies. Towards mainstreaming climate change in grassland management.

67. Towards mainstreaming climate change in grassland management policies and practices on the Tibetan Plateau

68. An Assessment of the Potential for Carbon Finance in Rangelands

69 ECA Trade-offs Among Ecosystem Services in the Lake Victoria Basin. 
69. The last remnants of mega biodiversity in West Java and Banten: an in-depth exploration of RaTA (Rapid Land Tenure Assessment) in Mount Halimun-Salak National Park Indonesia

70. Le business plan d'une petite entreprise rurale de production et de commercialisation des plants des arbres locaux. Cas de quatre pépinières rurales au Cameroun.

71. Les unités de transformation des produits forestiers non ligneux alimentaires au Cameroun. Diagnostic technique et stratégie de développement Honoré Tabuna et Ingratia Kayitavu.

72. Les exportateurs camerounais de safou (Dacryodes edulis) sur le marché sous régional et international. Profil, fonctionnement et stratégies de développement.

73. Impact of the Southeast Asian Network for Agroforestry Education (SEANAFE) on agroforestry education capacity.

74. Setting landscape conservation targets and promoting them through compatible land use in the Philippines.

75. Review of methods for researching multistrata systems.

76. Study on economical viability of Jatropha curcas L. plantations in Northern Tanzania assessing farmers' prospects via cost-benefit analysis

77. Cooperation in Agroforestry between Ministry of Forestry of Indonesia and International Center for Research in Agroforestry

78. "China's bioenergy future. an analysis through the Lens if Yunnan Province

79. Land tenure and agricultural productivity in Africa: A comparative analysis of the economics literature and recent policy strategies and reforms

80. Boundary organizations, objects and agents: linking knowledge with action in agroforestry watersheds

81. Reducing emissions from deforestation and forest degradation (REDD) in Indonesia: options and challenges for fair and efficient payment distribution mechanisms

2009

82. Mainstreaming climate change into agricultural education: challenges and perspectives

83. Challenging conventional mindsets and disconnects in conservation: the emerging role of eco-agriculture in Kenya's landscape mosaics

84. Lesson learned RATA garut dan bengkunat: suatu upaya membedah kebijakan pelepasan kawasan hutan dan redistribusi tanah bekas kawasan hutan

85. The emergence of forest land redistribution in Indonesia

86. Commercial opportunities for fruit in Malawi

87. Status of fruit production processing and marketing in Malawi

88. Fraud in tree science

89. Trees on farm: analysis of global extent and geographical patterns of agroforestry

90. The springs of Nyando: water, social organization and livelihoods in Western Kenya

91. Building capacity toward region-wide curriculum and teaching materials development in agroforestry education in Southeast Asia

92. Overview of biomass energy technology in rural Yunnan (Chinese - English abstract)

93. A pro-growth pathway for reducing net GHG emissions in China

94. Analysis of local livelihoods from past to present in the central Kalimantan Ex-Mega Rice Project area

95. Constraints and options to enhancing production of high quality feeds in dairy production in Kenya, Uganda and Rwanda

2010

96. Agroforestry education in the Philippines: status report from the Southeast Asian Network for Agroforestry Education (SEANAFE)

97. Economic viability of Jatropha curcas L. plantations in Northern Tanzania- assessing farmers' prospects via cost-benefit analysis.

98. Hot spot of emission and confusion: land tenure insecurity, contested policies and competing claims in the central Kalimantan Ex-Mega Rice Project area

99. Agroforestry competences and human resources needs in the Philippines

100. CES/COS/CIS paradigms for compensation and rewards to enhance environmental Services

101. Case study approach to region-wide curriculum and teaching materials development in agroforestry education in Southeast Asia 
102. Stewardship agreement to reduce emissions from deforestation and degradation (REDD): Lubuk Beringin's Hutan Desa as the first village forest in Indonesia

103. Landscape dynamics over time and space from ecological perspective

104. Komoditisasi atau koinvestasi jasa lingkungan: skema imbal jasa lingkungan program peduli sungai di DAS Way Besai, Lampung, Indonesia

105. Improving smallholders' rubber quality in Lubuk Beringin, Bungo district, Jambi province, Indonesia: an initial analysis of the financial and social benefits

106. Rapid Carbon Stock Appraisal (RACSA) in Kalahan, Nueva Vizcaya, Philippines

107. Tree domestication by ICRAF and partners in the Peruvian Amazon: lessons learned and future prospects in the domain of the Amazon Initiative eco-regional program

108. Memorias del Taller Nacional: "Iniciativas para Reducir la Deforestación en la región Andino - Amazónica", 09 de Abril del 2010. Proyecto REALU Peru

109. Percepciones sobre la Equidad y Eficiencia en la cadena de valor de REDD en Perú - Reporte de Talleres en Ucayali, San Martín y Loreto, 2009. Proyecto REALU-Perú.

110. Reducción de emisiones de todos los Usos del Suelo. Reporte del Proyecto REALU Perú Fase 1

111. Programa Alternativas a la Tumba-y-Quema (ASB) en el Perú. Informe Resumen y Síntesis de la Fase II. 2da. versión revisada

112. Estudio de las cadenas de abastecimiento de germoplasma forestal en la amazonía Boliviana

113. Biodiesel in the Amazon

114. Estudio de mercado de semillas forestales en la amazonía Colombiana

115. Estudio de las cadenas de abastecimiento de germoplasma forestal en Ecuador http://dx.doi.org10.5716/WP10340.PDF

116. How can systems thinking, social capital and social network analysis help programs achieve impact at scale?

117. Energy policies, forests and local communities in the Ucayali Region, Peruvian Amazon

118. NTFPs as a Source of Livelihood Diversification for Local Communities in the Batang Toru Orangutan Conservation Program

119. Studi Biodiversitas: Apakah agroforestry mampu mengkonservasi keanekaragaman hayati di DAS Konto?

120. Estimasi Karbon Tersimpan di Lahan-lahan Pertanian di DAS Konto, Jawa Timur

121. Implementasi Kaji Cepat Hidrologi (RHA) di Hulu DAS Brantas, Jawa Timur. http://dx.doi.org/10.5716/WP10338.PDF

122. Kaji Cepat Hidrologi di Daerah Aliran Sungai Krueng Peusangan, NAD,Sumatra http://dx.doi.org/10.5716/WP10337.PDF

123. A Study of Rapid Hydrological Appraisal in the Krueng Peusangan Watershed, NAD, Sumatra. http://dx.doi.org/10.5716/WP10339.PDF

2011

124. An Assessment of farm timber value chains in Mt Kenya area, Kenya

125. A Comparative financial analysis of current land use systems and implications for the adoption of improved agroforestry in the East Usambaras, Tanzania

126. Agricultural monitoring and evaluation systems

127. Challenges and opportunities for collaborative landscape governance in the East Usambara Mountains, Tanzania

128. Transforming Knowledge to Enhance Integrated Natural Resource Management Research, Development and Advocacy in the Highlands of Eastern Africa http://dx.doi.org/10.5716/WP11084.PDF

129. Carbon-forestry projects in the Philippines: potential and challenges The Mt Kitanglad Range forest-carbon development http://dx.doi.org10.5716/WP11054.PDF

130. Carbon forestry projects in the Philippines: potential and challenges. The Arakan Forest Corridor forestcarbon project http://dx.doi.org10.5716/WP11055.PDF

131. Carbon-forestry projects in the Philippines: potential and challenges. The Laguna Lake Development Authority's forest-carbon development project http://dx.doi.org/10.5716/WP11056.PDF

132. Carbon-forestry projects in the Philippines: potential and challenges. The Quirino forest-carbon development project in Sierra Madre Biodiversity Corridor http://dx.doi.org10.5716/WP11057.PDF

133. Carbon-forestry projects in the Philippines: potential and challenges. The Ikalahan Ancestral Domain forestcarbon development http://dx.doi.org10.5716/WP11058.PDF

134. The Importance of Local Traditional Institutions in the Management of Natural Resources in the Highlands of Eastern Africa http://dx.doi.org/10.5716/WP11085.PDF

135. Socio-economic assessment of irrigation pilot projects in Rwanda http://dx.doi.org/10.5716/WP11086.PDF 
136. Performance of three rambutan varieties(Nephelium lappaceum L.) on various nursery media http://dx.doi.org/10.5716/WP11232.PDF

137. Climate change adaptation and social protection in agroforestry systems: enhancing adaptive capacity and minimizing risk of drought in Zambia and Honduras http://dx.doi.org/10.5716/WP11269.PDF

138. Does value chain development contribute to rural poverty reduction? Evidence of asset building by smallholder coffee producers in Nicaragua http://dx.doi.org/10.5716/WP11271.PDF

139. Potential for biofuel feedstock in Kenya. http://dx.doi.org/10.5716/WP11272.PDF

140. Impact of fertilizer trees on maize production and food security in six districts of Malawi. http://dx.doi.org/10.5716/WP11281.PDF

2012

141. Fortalecimiento de capacidades para la gestión del Santuario Nacional Pampa Hermosa: Construyendo las bases para un manejo adaptativo para el desarrollo local. Memorias del Proyecto.

http://dx.doi.org/10.5716/WP12005.PDF

142. Understanding rural institutional strengthening: A cross-level policy and institutional framework for sustainable development in Kenya http://dx.doi.org/10.5716/WP12012.PDF

143. Climate change vulnerability of agroforestry http://dx.doi.org/10.5716/WP16722.PDF

144. Rapid assesment of the inner Niger delta of Mali http://dx.doi.org/10.5716/WP12021.PDF

145. Designing an incentive program to reduce on-farm deforestationin the East Usambara Mountains, Tanzania http://dx.doi.org/10.5716/WP12048.PDF

146. Extent of adoption of conservation agriculture and agroforestry in Africa: the case of Tanzania, Kenya, Ghana, and Zambia http://dx.doi.org/10.5716/WP12049.PDF

147. Policy incentives for scaling up conservation agriculture with trees in Africa: the case of Tanzania, Kenya, Ghana and Zambia http://dx.doi.org/10.5716/WP12050.PDF

148. Commoditized or co-invested environmental services? Rewards for environmental services scheme: River Care program Way Besai watershed, Lampung, Indonesia. http://dx.doi.org/10.5716/WP12051.PDF

149. Assessment of the headwaters of the Blue Nile in Ethiopia. http://dx.doi.org/10.5716/WP12160.PDF

150. Assessment of the uThukela Watershed, Kwazaulu. http://dx.doi.org/10.5716/WP12161.PDF

151. Assessment of the Oum Zessar Watershed of Tunisia. http://dx.doi.org/10.5716/WP12162.PDF

152. Assessment of the Ruwenzori Mountains in Uganda. http://dx.doi.org/10.5716/WP12163.PDF

153. History of agroforestry research and development in Viet Nam. Analysis of research opportunities and gaps. http://dx.doi.org/10.5716/WP12052.PDF

154. REDD+ in Indonesia: a Historical Perspective. http://dx.doi.org/10.5716/WP12053.PDF

155. Agroforestry and Forestry in Sulawesi series: Livelihood strategies and land use system dynamics in South Sulawesi http://dx.doi.org/10.5716/WP12054.PDF

156. Agroforestry and Forestry in Sulawesi series: Livelihood strategies and land use system dynamics in Southeast Sulawesi. http://dx.doi.org/10.5716/WP12055.PDF

157. Agroforestry and Forestry in Sulawesi series: Profitability and land-use systems in South and Southeast Sulawesi. http://dx.doi.org/10.5716/WP12056.PDF

158. Agroforestry and Forestry in Sulawesi series: Gender, livelihoods and land in South and Southeast Sulawesi http://dx.doi.org/10.5716/WP12057.PDF

159. Agroforestry and Forestry in Sulawesi series: Agroforestry extension needs at the community level in AgFor project sites in South and Southeast Sulawesi, Indonesia. http://dx.doi.org/10.5716/WP12058.PDF

160. Agroforestry and Forestry in Sulawesi series: Rapid market appraisal of agricultural, plantation and forestry commodities in South and Southeast Sulawesi. http://dx.doi.org/10.5716/WP12059.PDF

2013

161. Diagnosis of farming systems in the Agroforestry for Livelihoods of Smallholder farmers in Northwestern Viet Nam project http://dx.doi.org/10.5716/WP13033.PDF

162. Ecosystem vulnerability to climate change: a literature review. http://dx.doi.org/10.5716/WP13034.PDF

163. Local capacity for implementing payments for environmental services schemes: lessons from the RUPES project in northeastern Viet Nam http://dx.doi.org/10.5716/WP13046.PDF

164. Seri Agroforestri dan Kehutanan di Sulawesi: Agroforestry dan Kehutanan di Sulawesi: Strategi mata pencaharian dan dinamika sistem penggunaan lahan di Sulawesi Selatan http://dx.doi.org/10.5716/WP13040.PDF

165. Seri Agroforestri dan Kehutanan di Sulawesi: Mata pencaharian dan dinamika sistem penggunaan lahan di Sulawesi Tenggara http://dx.doi.org/10.5716/WP13041.PDF

166. Seri Agroforestri dan Kehutanan di Sulawesi: Profitabilitas sistem penggunaan lahan di Sulawesi Selatan dan Sulawesi Tenggara http://dx.doi.org/10.5716/WP13042.PDF 
167. Seri Agroforestri dan Kehutanan di Sulawesi: Gender, mata pencarian dan lahan di Sulawesi Selatan dan Sulawesi Tenggara http://dx.doi.org/10.5716/WP13043.PDF

168. Seri Agroforestri dan Kehutanan di Sulawesi: Kebutuhan penyuluhan agroforestri pada tingkat masyarakat di lokasi proyek AgFor di Sulawesi Selatan dan Tenggara, Indonesia http://dx.doi.org/10.5716/WP13044.PDF

169. Seri Agroforestri dan Kehutanan di Sulawesi: Laporan hasil penilaian cepat untuk komoditas pertanian, perkebunan dan kehutanan di Sulawesi Selatan dan Tenggara http://dx.doi.org/10.5716/WP13045.PDF

170. Agroforestry, food and nutritional security http://dx.doi.org/10.5716/WP13054.PDF

171. Stakeholder Preferences over Rewards for Ecosystem Services: Implications for a REDD+ Benefit Distribution System in Viet Nam http://dx.doi.org/10.5716/WP13057.PDF

172. Payments for ecosystem services schemes: project-level insights on benefits for ecosystems and the rural poor http://dx.doi.org/10.5716/WP13001.PDF

173. Good practices for smallholder teak plantations: keys to success http://dx.doi.org/10.5716/WP13246.PDF

174. Market analysis of selected agroforestry products in the Vision for Change Project intervention Zone, Côte d'Ivoire http://dx.doi.org/10.5716/WP13249.PDF

175. Rattan futures in Katingan: why do smallholders abandon or keep their gardens in Indonesia's 'rattan district'? http://dx.doi.org/10.5716/WP13251.PDF

176. Management along a gradient: the case of Southeast Sulawesi's cacao production landscapes http://dx.doi.org/10.5716/WP13265.PDF

2014

177. Are trees buffering ecosystems and livelihoods in agricultural landscapes of the Lower Mekong Basin? Consequences for climate-change adaptation. http://dx.doi.org/10.5716/WP14047.PDF

178. Agroforestry, livestock, fodder production and climate change adaptation and mitigation in East Africa: issues and options. http://dx.doi.org/10.5716/WP14050.PDF

179. Trees on farms: an update and reanalysis of agroforestry's global extent and socio-ecological characteristics. http://dx.doi.org/10.5716/WP14064.PDF

180. Beyond reforestation: an assessment of Vietnam's REDD+ readiness. http://dx.doi.org/10.5716/WP14097.PDF

181. Farmer-to-farmer extension in Kenya: the perspectives of organizations using the approach. http://dx.doi.org/10.5716/WP14380.PDF

182. Farmer-to-farmer extension in Cameroon: a survey of extension organizations. http://dx.doi.org/10.5716/WP14383.PDF

183. Evaluating indicators of land degradation and targeting Agroforestry interventions in smallholder farming systems in Ethiopia http://dx.doi.org/10.5716/WP14384.PDF

184. Seri Agroforestri dan Kehutanan di Sulawesi: Kuantifikasi jasa lingkungan air dan karbon pola agroforestri pada hutan rakyat di wilayah sungai Jeneberang http://dx.doi.org/10.5716/WP14391.PDF

185. Options for Climate-Smart Agriculture at Kaptumo Site in Kenya. http://dx.doi.org/10.5716/WP14394.PDF

186. Agroforestry for Landscape Restoration and Livelihood Development in Central Asia http://dx.doi.org/10.5716/WP14143.PDF

187. Projected Climate Change and Impact on Bioclimatic Conditions in the Central and South-Central Asia Region http://dx.doi.org/10.5716/WP14144.PDF 

The World Agroforestry Centre is an autonomous, non-profit research organization whose vision is a rural transformation in the developing world as smallholder households increase their use of trees in agricultural landscapes to improve food security, nutrition, income, health, shelter, social cohesion, energy resources and environmental sustainability. The Centre generates science-based knowledge about the diverse roles that trees play in agricultural landscapes, and uses its research to advance policies and practices, and their implementation that benefit the poor and the environment. It aims to ensure that all this is achieved by enhancing the quality of its science work, increasing operational efficiency, building and maintaining strong partnerships, accelerating the use and impact of its research, and promoting greater cohesion, interdependence and alignment within the organization.

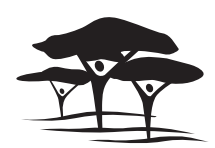

United Nations Avenue, Gigiri • PO Box 30677 • Nairobi, $00100 \cdot$ Kenya Telephone: +254 207224000 or via USA +1 6508336645 Fax: +254207224001 or via USA +1 6508336646 Email: worldagroforestry@cgiar.org•www.worldagroforestry.org

Southeast Asia Regional Program • Sindang Barang • Bogor 16680 PO Box $161 \cdot$ Bogor $16001 \cdot$ Indonesia

Telephone: +62 $2518625415 \cdot$ Fax: +62 2518625416 